\title{
Antiinflammatory and Immunomodulating Properties of Fungal Metabolites
}

\author{
Cristina Lull, ${ }^{1}$ Harry J. Wichers, ${ }^{1}$ and Huub F. J. Savelkoul ${ }^{2}$ \\ ${ }^{1}$ Agrotechnology and Food Innovations, Wageningen University and Research Center, \\ Bornsesteeg 59, 6708 PD Wageningen, The Netherlands \\ ${ }^{2}$ Cell Biology and Immunology Group, Wageningen University and Research Center, \\ Marijkeweg 40, 6709 PG Wageningen, The Netherlands
}

Received 22 December 2004; accepted 25 January 2005

\begin{abstract}
We discuss current information on the ability of extracts and isolated metabolites from mushrooms to modulate immune responses. This can result in a more enhanced innate and acquired disease resistance. The major immunomodulating effects of these active substances derived from mushrooms include mitogenicity and activation of immune effector cells, such as lymphocytes, macrophages, and natural killer cells, resulting in the production of cytokines, including interleukins (ILs), tumor necrosis factor alpha (TNF)- $\alpha$, and interferon gamma (INF) $-\gamma$. In particular, the ability of selective mushroom extracts to modulate the differentiation capacity of $\mathrm{CD}^{+} \mathrm{T}$ cells to mature into $\mathrm{T}_{\mathrm{H}} 1$ and/or $\mathrm{T}_{\mathrm{H}} 2$ subsets will be discussed. As a consequence these extracts will have profound effects in particular diseases, like chronic autoimmune $\mathrm{T}_{\mathrm{H}} 1$-mediated or allergic $\mathrm{T}_{\mathrm{H}} 2$-mediated diseases. Immunosuppressive effects by mushroom components have also been observed. The therapeutic effects of mushrooms, such as anticancer activity, suppression of autoimmune diseases, and allergy have been associated with their immunomodulating effects. However, further studies are needed to determine the molecular mechanisms of the immunomodulating effects of mushrooms metabolites both individually and in complex mixtures, for example, extracts.
\end{abstract}

\section{INTRODUCTION}

The number of different mushroom species on earth is estimated at 140000 , of which may be only $10 \%$ are known. Meanwhile, of those approximately 14000 species that we know today, about $50 \%$ are considered to possess varying degrees of edibility, more than 2000 are safe, and about 700 species are known to possess significant pharmacological properties $[1,2,3,4]$. Mushrooms have long been attracting a great deal of interest in many areas of foods and biopharmaceuticals. They are well known for their nutritional and medicinal values $[1,4,5,6,7,8,9]$. In accordance to Breene [10] the gross composition of mushrooms is water (90\%), and from the dry matter: protein $(10 \%-40 \%)$, fat $(2 \%-8 \%)$, carbohydrates $(3 \%-28 \%)$, fiber $(3 \%-32 \%)$, and ash $(8 \%-10 \%)$ (the ash percentage

Correspondence and reprint requests to Huub F. J. Savelkoul, Cell Biology and Immunology Group, Wageningen University and Research Center, Marijkeweg 40, 6709 PG Wageningen, The Netherlands; huub.savelkoul@wur.nl

This is an open access article distributed under the Creative Commons Attribution License which permits unrestricted use, distribution, and reproduction in any medium, provided the original work is properly cited. is the fraction of dry matter that remains after incineration of the organic material in a sample, and is mainly composed of salts, metals, and so forth). Many species of mushrooms are cultivated worldwide. Global production increased to about 6.2 million tons in 1997, with a more than 12\% increase annually from 1981 to 1997 [11]. Mushroom extracts have been increasingly sold as dietary supplements. The market value of mushroom dietary supplement products worldwide is about US\$5-6 billion per year [12].

Medicinal mushrooms have an established history of use in traditional oriental therapies. Historically, hotwater-soluble fractions (decoctions and essences) from medicinal mushrooms were used as medicine in the Far East, where knowledge and practice of mushroom use primarily originated $[4,13,14]$. Mushrooms such as Ganoderma lucidum (Reishi), Lentinus edodes (Shiitake), Inonotus obliquus (Chaga), and many others have been collected and used for hundreds of years in Korea, China, Japan, and eastern Russia [4].

Mushroom metabolites are increasingly being utilized to treat a wide variety of diseases, particularly as they can be added to the diet and used orally, without the need to go through phase-I/II/III trials as an ordinary medicine, and they are considered as a safe and useful approach for disease treatment. A lot of scientific 


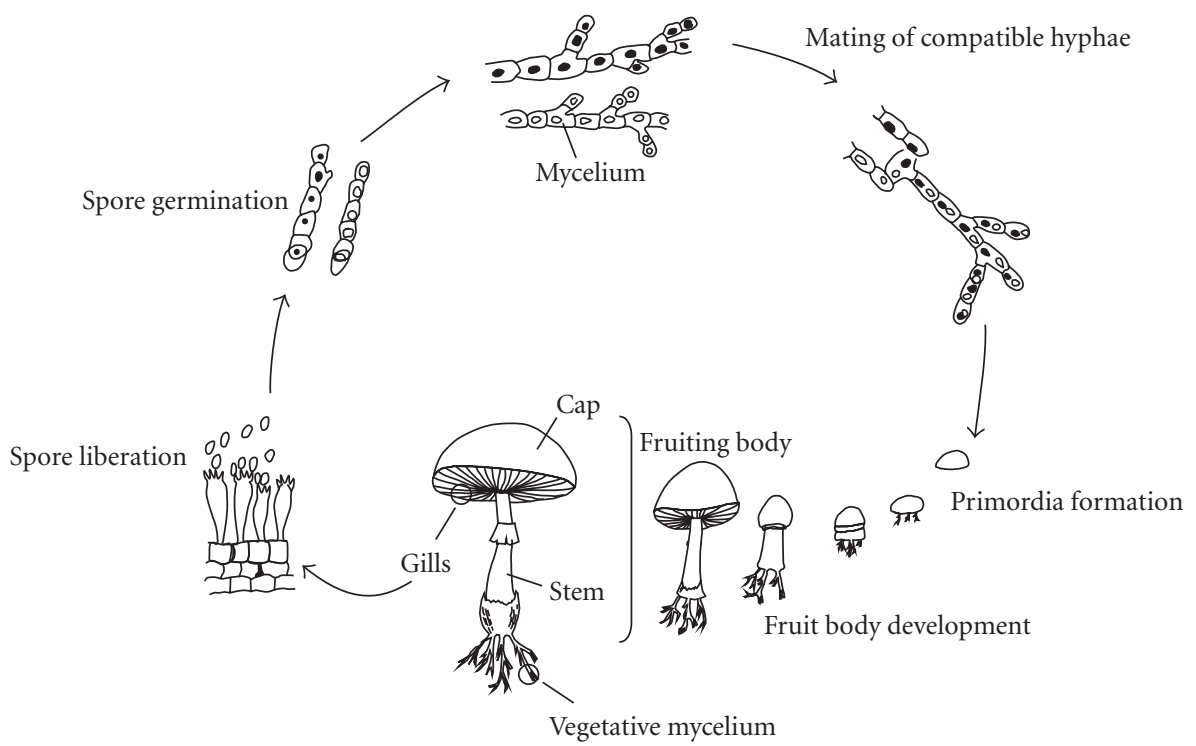

Figure 1. Diagrammatic representation of mushroom life cycle.

investigations have been performed to discover possible functional properties, which could be efficient in possible treatments of diseases like allergic asthma [15, 16, 17], food allergy [18, 19], atopic dermatitis [20], inflammation $[21,22]$, autoimmune joint inflammation such as rheumatoid arthritis [23], atherosclerosis [24, 25], hyperglycemia [26], thrombosis [27], human immunodeficiency virus (HIV) infection [28, 29], listeriosis [30], tuberculosis [31], septic shock [32], and cancer [33, 34, 35, $36,37,38,39,40,41,42,43,44,45,46,47,48,49,50,51$, $52,53,54,55]$.

In the last years many researchers have studied the possibility that extracts and isolated metabolites from mushrooms stimulate or suppress specific components of the immune system. Immunomodulators can be effective agents for treating and preventing diseases and illnesses that stem from certain immunodeficiencies and other depressed states of immunity [56]. Synonymous terms for immunomodulators include biological response modifiers, immunoaugmentors, or immunorestoratives [57]. Those metabolites which appear to stimulate the human immune response are being sought for the treatment of cancer, immunodeficiency diseases, or for generalized immunosuppression following drug treatment, for combination therapy with antibiotics, and as adjuvants for vaccines [58]. Those metabolites that suppress immune reactions are potentially useful to mitigate autoimmune or certain gastrointestinal tract diseases (eg, Crohn's) [59].

At least 651 species and 7 infraspecific taxa representing 182 genera of hetero- and homobasidiomycetes mushrooms contain antitumor or immunostimulating metabolites [4]. Bioactive metabolites can be isolated from fruiting bodies (Figure 1), pure culture mycelia, and culture filtrate (culture broth). Nowadays many attempts are being made to obtain bioactive metabolites from mycelia through submerged fermentation culture. The cultivation of mushrooms to produce fruiting bodies is a long-term process requiring from one to several months for the first fruiting bodies to appear. The growth of mushroom cell cultures in submerged conditions in a liquid culture medium accelerates the process, resulting in biomass yield within a few days and allows to obtain standardized nutriceutical substances.

Several major substances with immunomodulatory and/or antitumor activity have been isolated from mushrooms. These include mainly polysaccharides (in particular $\beta$-D-glucans (Figure 2)), polysaccharopeptides (PSP), polysaccharide proteins, and proteins. Furthermore, other bioactive substances, including triterpenes, lipids, and phenols, have been identified and characterized in mushrooms with proven medicinal properties. The major immunomodulating effects of these active substances derived from mushrooms include mitogenicity and activation of immune cells, such as hematopoietic stem cells, lymphocytes, macrophages, dendritic cells (DCs) and natural killer (NK) cells, resulting in the production of cytokines. The therapeutic effects of mushrooms, such as anticancer activity, suppression of autoimmune diseases, and allergy have been associated in many cases with their immunomodulating effects.

Whilst it is known that mushroom extracts have immunomodulatory and/or antitumor activity, the standard approach has been to isolate, characterize, and administer the pure active constituents. However, different components in a mushroom extract may have synergistic activities $[49,60]$. There are several reports of mushrooms containing more than one polysaccharide with antitumor activity. The responses to different polysaccharides are likely to be mediated by different cell surface receptors, which may be present only on specific subsets of cells and may 


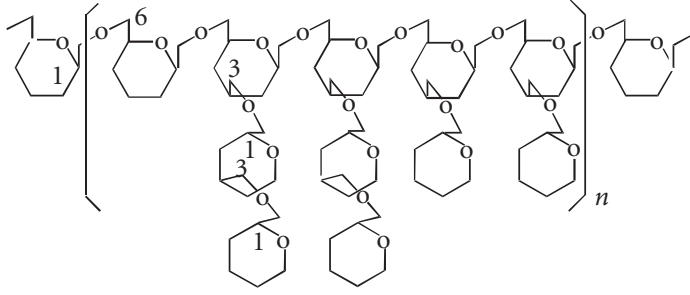

(a)

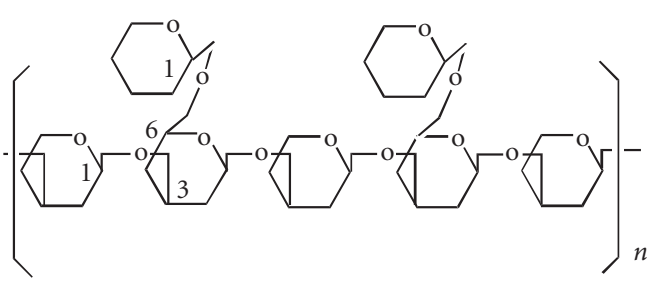

(b)

FIGURE 2. Repeating unit of immunomodulatory $\beta$-glucans (a) from Grifola frondosa (D-fraction, MW: $1000 \mathrm{kD}$ ) and (b) from $L$ edodes (lentinan, MW: $500 \mathrm{kD}$ ).

TABLE 1. Immunomodulatory activities of mushroom compounds on hematopoietic stem cells.

\begin{tabular}{|c|c|c|c|}
\hline Species & Compound & Immune effects & Reference \\
\hline Grifola frondosa & MD-fraction & $\begin{array}{l}\uparrow \text { BMCs growth and differentiation into CFU-GM } \\
\uparrow \text { recovery of CFU-GM response after DOX induced hematopoietic suppression }\end{array}$ & {$[61]$} \\
\hline Lentinus lepideus & PG101 & $\begin{array}{l}\uparrow \text { CFU-GM, BFU-E, IL- } 1 \beta, \text { IL-6, GM-CSF } \\
\downarrow \text { TNF- } \alpha \text { in irradiated mice }\end{array}$ & [63] \\
\hline Sparassis crispa & SCG & $\begin{array}{l}\uparrow \text { granulocytes, monocytes, } \gamma \delta \mathrm{T} \text { cells and NK1.1 cells in the peripheral cells in } \\
\mathrm{CY} \text {-induced leukopenia }\end{array}$ & {$[64]$} \\
\hline
\end{tabular}

trigger distinct downstream responses. A combination of such responses involving different cell subsets could conceivably provide greater tumor inhibition than could be induced by a single polysaccharide [49].

\section{EFFECTS OF MUSHROOM METABOLITES ON HEMATOPOIETIC STEM CELLS}

Various metabolites, especially carbohydrates isolated from mushrooms, were reported to affect bone marrow cells (BMCs), and to induce hematopoiesis (Table 1). Recently, Lin et al [61] reported that Maitake MD-fraction (obtained by further purification of Dfraction), an extract isolated from the fruit body of Grifola frondosa whose active component is an isolated $\beta$-glucan, a protein-bound polysaccharide compound, caused direct enhancement of the colony-forming unitsgranulocytes/macrophages (CFU-GM) response of BMCs progenitors and enhanced recovery of the CFU-GM response after doxorubicin (DOX) induced hematopoietic suppression. These studies suggest that MD-fraction has the potential to reduce hematopoietic suppression induced by chemotherapy.

PG101, a water-soluble extract that consists of protein-bound polysaccharides, isolated from cultured mycelia of Lentinus lepideus [62], is a potent immune modulator that recovers the radiation-damaged bone marrow system very efficiently. In PG101-treated mice, the number of CFU-GM and erythroid burst-forming units (BFU-E) were increased to almost the levels seen in nonirradiated control as early as 8 days after irradiation. Radiation is known to result in serious dysregu- lation of cytokine expression. PG101 increased the levels of IL- $1 \beta$, IL- 6 , and granulocyte macrophage-colonystimulating factor (GM-CSF) over the 24-day period. PG101 significantly reduced the level of TNF- $\alpha$. TNF- $\alpha$, which is increased as a consequence of tissue injury and anemia due to radiation, is thought to be a key mediator for the pathogenesis of radiation damage. Thus, PG101 showed great potential as a supplement or a major therapeutics in immunocompromised or immunosuppressed individuals whose bone marrow system is damaged [63].

SCG, a $\beta$ - $(1 \rightarrow 3)$-D-glucan with $\beta$ - $(1 \rightarrow 6)$ branches isolated from fruit bodies of Sparassis crispa, enhanced the hematopoietic response in cyclophosphamide- (CY) induced leukopenic mice by intraperitoneal routes over a wide range of concentrations. Monocytes and granulocytes in the peritoneal cavity, liver, spleen, and bone marrow recovered faster than in the control group. The ratio of NK cells and $\gamma \delta \mathrm{T}$ cells in the liver, spleen, and peritoneal cavity was also increased. These results suggest the usefulness of S crispa in cancer immunotherapy [64].

\section{EFFECTS OF MUSHROOM METABOLITES ON THE INNATE IMMUNE SYSTEM}

\section{Macrophages}

The recognition of microbes by macrophages and neurophilic granulocytes leads to phagocytosis of the microbes and activation of the phagocytes to kill the ingested microbes. Recognition is mediated by toll-like receptors (TLR) that are specific for different components of microbes. TLR-2 binds lipogycans, TLR-4 binds bacterial 
lipopolysaccharide (LPS), TLR-5 binds flagellin, and TLR9 binds unmethylated CpG nucleotides present in bacteria. As a consequence of recognition and phagocytosis several enzymes are activated, including oxidases and inducible nitric oxide synthase (iNOS), resulting in the production of bacteriocidal reactive oxygen intermediates (ROI) and nitric oxide (NO).

The effects of mushroom extracts and metabolites on macrophages have been extensively studied in vitro and in vivo. Some mushroom metabolites activate macrophages to produce various mediators, even in normal mice. Activities are summarized in Table 2.

Water extracts of the mycelial culture and fruiting bodies of Agaricus blazei Murill induced TNF- $\alpha$ secretion by macrophages derived from rat bone marrow. Fractions B-4 and B-5 obtained from ethanol precipitation of fruiting bodies markedly induced TNF- $\alpha$ secretion. Similar effects were observed in IL- 8 secretion by macrophages. Regarding NO, fraction B-5 induced a significant increase in NO secretion and fractions B-4 and B-6 slightly induced NO secretion. Northern blot analysis showed that the increases in cytokine and $\mathrm{NO}$ secretion were due to an increase in cytokine mRNAs or NO synthase mRNA [65]. Thus A blazei Murill contains certain components which activate macrophages contributing to the immune response in vitro.

Wang et al [66] reported that after treatment of macrophage cultures with a polysaccharide from fresh fruiting bodies of G lucidum, the levels of IL- $1 \beta$, TNF- $\alpha$, and IL-6 were 5.1-, 9.8-, and 29-fold higher than in cultures of untreated cells. In addition, the release of INF$\gamma$ from $\mathrm{T}$ lymphocytes was also greatly enhanced in the presence of this polysaccharide. This proinflammatory cytokine response is suggested to facilitate the antitumor activity of this extract.

Grifolan (GRN), an antitumor $\beta$-glucan isolated from $G$ frondosa induced the release of IL-1, IL- 6 and TNF- $\alpha$ from macrophages [67, 68]. Ishibashi et al [69] reported that an insoluble as well as a high-molecular-mass soluble form of GRN are required for TNF- $\alpha$ production by macrophages.

The effect of Maitake D-fraction was studied by Sanzen et al [70] on the iNOS-mediated NO production in RAW264.7 macrophages with special reference to antitumor activity of MD-fraction against human hepatomaderived huH-1 cells and the data suggested that MDfraction is a novel inducer for iNOS which contributes at least in part to antitumor activity of MD-fraction.

Kodama et al [30] examined the effects of Maitake $\mathrm{D}$-fraction on the treatment of Listeria-infected mice in combination with vancomycine (VCM). In mice administered with both $\mathrm{D}$-fraction and VCM, macrophages produced 2.7 times as much IL-1 $\beta$ as that of nontreated control mice. The bactericidal activity of splenic $\mathrm{T}$ cells was also enhanced by 2.6 times of that of nontreated control mice. These results suggest a clinical benefit of D-fraction in the case of antibacterial treatment for patients with high risks.
Monocytes/macrophages seem to be the major target cell type responsive to PG101. Jin et al [62] proposed that PG101 interacts with macrophages or related cells and results in the activation of the transcription factor nuclear factor kappa B (NF- $\kappa \mathrm{B})$, which sets off a series of reactions producing a variety of proinflammatory and antiinflammatory cytokines (TNF- $\alpha$, IL-1 $\beta$, IL-10, IL-12, GM-CSF, IL-18) in a sequential manner. Inflammatorycytokine-induced phosphorylation of a degradative motif in $\mathrm{I} \kappa \mathrm{B}$ triggers $\mathrm{I} \kappa \mathrm{B}$ proteolysis, liberating NF- $\kappa \mathrm{B}$ from the inactive heterodimer and NF- $\kappa \mathrm{B}$ transcription which in turn prevents cytokine-induced death of inflammatory cells. Despite its significant biological effect on various cytokines, PG101 remained nontoxic in both rats and human peripheral blood mononuclear cells (hPBMCs) even at a biological concentration approximately 20 times greater. PG101 demonstrates great potential as a therapeutic immune modulator.

A galactomannan isolated from a polar extract of Morchella esculenta carpophores enhanced macrophage activation. At $3.0 \mu \mathrm{g} / \mathrm{mL}$ the galactomannan polysaccharide (about $2.4 \%$ protein) increased NF- $\kappa \mathrm{B}$-directed luciferase expression in THP-1 human monocytic cells to levels of $50 \%$ of those achieved by maximal activating concentration $(10.0 \mu \mathrm{g} / \mathrm{mL})$ of LPS [71].

By administering PL, an acidic polysaccharide isolated from Phellinus linteus, the production of $\mathrm{NO}$ and tumoricidal activity were increased in murine peritoneal macrophages in vivo and in vitro. PL has been claimed to cause the inhibition of tumor growth and metastasis of murine B16F10 melanoma cells [72]. Such properties of PL may be related to its ability to induce the production of the tumoricidal effector molecule NO through protein tyrosine kinase (PTK) and protein kinase C (PKC) [73]. Considering the main role that proinflammatory cytokine production plays in the pathogenesis of septic shock, Kim et al [32] examined how the in vivo administration of PL can modulate circulating cytokine responses in LPStreated mice. Administration of PL in vivo decreased IL2 , IFN- $\gamma$, and TNF- $\alpha$ production in splenocytes and enhanced spontaneous cell apoptosis in macrophages and lymphocytes stimulated with LPS in vitro. Thus, part of the antiinflammatory effects of PL treatment in vivo may result from the enhanced apoptosis of a portion of the activated macrophages and lymphocytes. The ability of PL to significantly reduce TNF- $\alpha$ production indicates the potential of the polysaccharides in possible therapeutic strategies that are based on down regulation of TNF- $\alpha$ [32].

The methanol extract of fruit bodies of Cordyceps pruinosa inhibited IL- $1 \beta$, TNF- $\alpha$, NO, and prostaglandin $\mathrm{E}_{2}\left(\mathrm{PGE}_{2}\right)$ in vitro and in vivo. The extract inhibited these inflammatory mediators in LPS-stimulated murine macrophage cell line RAW264.7 and primary macrophages, by suppressing gene expression of IL-1 $\beta$, TNF- $\alpha$, iNOS, and cyclooxygenase-2 (COX-2) through the inhibition of NF- $\kappa$ B activation. Administration of the extract significantly decreased the plasma level of these 
TABLE 2. Immunomodulatory activities of mushroom products on macrophages.

\begin{tabular}{|c|c|c|c|}
\hline Species & Product & Immune effects & Reference \\
\hline G frondosa & D-fraction & $\uparrow \mathrm{IL}-1 \beta$ & {$[30]$} \\
\hline Llepideus & PG101 & $\uparrow$ TNF- $\alpha$, IL- $1 \beta$, IL-10, IL-12, GM-CSF, IL-18 & {$[62]$} \\
\hline \multirow{2}{*}{ A blazei } & Water extracts mycelia and fruit bodies & $\uparrow \mathrm{TNF}-\alpha$ & \multirow{2}{*}[65]{} \\
\hline & Fractions B-4 and B-5 & $\uparrow \mathrm{TNF}-\alpha$, IL-8, NO & \\
\hline Glucidum & Polysaccharide & $\uparrow \mathrm{IL}-1 \beta, \mathrm{TNF}-\alpha, \mathrm{IL}-6$ & {$[66]$} \\
\hline G frondosa & GRN & $\uparrow$ IL-1, IL-6, TNF- $\alpha$ & {$[67,68,69]$} \\
\hline G frondosa & MD-fraction & $\uparrow$ iNOS & {$[70]$} \\
\hline M esculenta & Galactomannan & $\uparrow$ macrophage activity & {$[71]$} \\
\hline P linteus & PL & $\begin{array}{l}\uparrow \text { NO } \\
\downarrow \text { IL-2, IFN- } \gamma \text {, and TNF- } \alpha \text { production in splenocytes } \\
\downarrow \text { apoptosis of a portion of the activated } \\
\text { macrophages and lymphocytes in LPS-treated mice }\end{array}$ & {$[72,73]$} \\
\hline Cpruinosa & Methanol extract & Inhibit IL- $1 \beta$, TNF- $\alpha, \mathrm{NO}, \mathrm{PGE}_{2}$ & {$[74]$} \\
\hline$S$ aspratus & Fucogalactan & $\uparrow \mathrm{TNF}-\alpha, \mathrm{NO}$ & {$[75]$} \\
\hline A cylindracea & Ubiquitin-like peptide & $\uparrow \mathrm{NO}$ & {$[77]$} \\
\hline T mongolicum & Lectins (TML-1, TML-2) & $\uparrow$ TNF- $\alpha$, Nitrite ions & [78] \\
\hline
\end{tabular}

inflammatory mediators in LPS-injected mice. These results suggest that the $C$ pruinosa methanol extract suppresses inflammation through suppression of NF- $\kappa \mathrm{B}$ dependent inflammatory gene expression, suggesting that the $C$ pruinosa extract may be beneficial for treatment of endotoxin shock or sepsis [74]. Also, the methanol extract of fruit bodies of Pleurotus florida showed antiinflammatory and antiplatelet-aggregating activities but the exact mechanism for these activities is unknown [21].

A fucogalactan, isolated from Sarcodon aspratus, elicited the release of TNF- $\alpha$ and NO in macrophages of mice in vitro. TNF- $\alpha$ production induced with $50 \mu \mathrm{g} / \mathrm{mL}$ of fucogalactan was significantly higher than that induced by lentinan $(500 \mu \mathrm{g} / \mathrm{mL})$ by approximately 4.3 -fold. Mizuno et al [75] suggested that the immunomodulating activity of this fucogalactan on TNF- $\alpha$ and NO productions might contribute to antituor activity in tumorbearing hosts as well as various immunomodulating effects.

In mice treated with an immunosuppressive carcinogen, administration of a mushroom-enriched diet containing $L$ edodes, $G$ frondosa, and Pleurotus ostreatus restored the normal level of the chemotactic activity of macrophages and the capability of lymphocytes to proliferate in response to mitogen [76].

Proteins and peptides from mushrooms are also known to activate macrophages. A ubiquitin-like peptide isolated from fruiting bodies of the mushroom Agrocybe cylindracea enhanced NO production in murine peritoneal macrophages with a potency comparable to that of LPS [77]. Two lectins isolated from the mushroom Tricholoma mongolicum (TML-1 and TML-2) stimulated the production of nitrite ions and TNF- $\alpha$ by macrophages in normal and tumor-bearing mice [78].

\section{Natural killer cells}

Natural killer cells are a class of lymphocytes that rapidly respond to intracellular infections with viruses or bacteria, by killling the infected cells and by producing the macrophage-activating cytokine, IFN- $\gamma$.

Some mushroom metabolites exhibit stimulating effects on NK cells (Table 3). Innate immunity is in the critical arms of immune surveillance against tumor development. Moreover, in the innate immune system, NK cells, which do not express T-cell receptors that recognize specific peptides presented on the major histocompatibility complex (MHC), rather than T cells, seem well suited for this role. NK cells can recognize the surface changes that occur on a variety of tumor cells and virally infected cells [79]. NK cells have two relevant functions, related to the natural immune response against pathogens [80]. One is cytotoxicity, mediated by the recognition and lysis of target cells such as virus- and bacteria-infected cells. The second NK cells function is to produce cytokines such as IFN- $\gamma$, TNF- $\alpha$, and GM-CSF, that can modulate natural and specific immune responses. Additionally, infected or activated DCs and macrophages produce cytokines and chemokines such as IFN- $\alpha / \beta$, IL-12, IL-15, and IL-18 that stimulate NK cells to rapidly produce other cytokines (including IFN- $\gamma$, TNF- $\alpha$, and GM-CSF) and chemokines (such as ATAC/lymphotactin, mig, and MIP$1 \alpha)[81]$.

Kodama et al [41, 82] monitored levels of NK cell cytotoxic activity in cancer patients receiving D-fraction. Elevated levels of cytotoxic activity were maintained for one year. To elucidate the mechanisms underlying long-term activation of NK cells during treatment with D-fraction, the authors examined tumor volume and levels of IFN- $\gamma$ and TNF- $\alpha$ in MM46-bearing $\mathrm{C} 3 \mathrm{H} / \mathrm{HeN}$ mice to which D-fraction was administered for 19 days. D-fraction 
TABLE 3. Immunomodulatory activities of mushroom products on NK cells.

\begin{tabular}{|c|c|c|c|}
\hline Species & Compound & Immune effects & Reference \\
\hline$G$ frondosa & D-fraction & $\begin{array}{l}\uparrow \text { TNF- } \alpha \text {, IFN- } \gamma \text { released from spleen cells; TNF- } \alpha \text { expressed } \\
\text { in NK cells in tumor-bearing mice } \\
\uparrow \text { NK cells activity (INF- } \gamma \text { ) indirectly through IL-12 produced by } \\
\text { macrophages and DCs in normal mice }\end{array}$ & {$[41,82,83,84]$} \\
\hline A blazei & $\begin{array}{l}\text { Hot-water extract } \\
n \text {-hexane }\end{array}$ & $\uparrow \mathrm{NK}$ activity of spleen cells in naïve BALB/c mice & {$[85]$} \\
\hline A blazei & $\begin{array}{l}\text { Dichloromethane } \\
\text { Methanol }\end{array}$ & Maintain NK activity of spleen cells in tumor-bearing mice & [87] \\
\hline A blazei & ABMK & $\uparrow \mathrm{NK}$ activity on cancer patients & [88] \\
\hline
\end{tabular}

markedly suppressed tumor growth, corresponding with increases in TNF- $\alpha$ and IFN- $\gamma$ released from spleen cells and a significant increase in TNF- $\alpha$ expressed in NK cells. Furthermore, D-fraction increased macrophage-derived IL-12, which serves to activate NK cells. Thus, NK cells are not only responsible for the early effects of $\mathrm{D}$-fraction on tumor growth, but also for the long-term tumorsuppressive effects of D-fraction through increased IL-12 released from macrophages. D-fraction was capable of enhancing and maintaining peripheral blood NK cell activity in patients with lung and breast cancer [41]. In addition, Maitake D-fraction, stimulated the natural immunity related to the activation of NK cells indirectly through IL-12 produced by macrophages and DCs in normal mice [83]. IFN- $\gamma$ production by splenic NK cells increased significantly 3 days after $\mathrm{D}$-fraction administration. In a recent study, Kodama et al [84] reported the activation of macrophages and DCs in normal mice as well. Therefore, administration of D-fraction to healthy individuals may serve to prevent infection by microorganisms.

Treatment with hot-water extracts of $A$ blazei fruiting bodies increased $\mathrm{NK}$ activity of spleen cells in naïve $\mathrm{BALB} / \mathrm{c}$ mice [85]. In meth A-bearing $\mathrm{BALB} / \mathrm{c}$ mice, the same extracts enhanced the induction of antigen-specific cytotoxic T lymphocytes $\left(\mathrm{T}_{\mathrm{C}}\right)$ and IFN- $\gamma$ production. Up regulation of $\mathrm{NK}$ and $\mathrm{T}_{\mathrm{C}}$ activity is triggered by IL-12dependent activation [86]. It is not yet clear whether oral administration of Agaricus extracts enhances IL-12 production in vivo [85].

Ehrlich-carcinoma-bearing mice treated with the $n$ hexane, dichloromethane, or methanol extracts from $A$ blazei fruiting bodies were able to maintain the NK activity of spleen cells during the first 10 days after tumor implantation. The NK activity of these groups was similar to that of normal controls and higher than that of tumor-bearing mice treated with water. The results of NK activity on the 30th day after the injection of tumor cells suggest that none of the three extracts was able to maintain the lytic activity against Yac-1 target cells. It is possible that after 30 days the production of soluble factors like prostaglandins, TGF- $\beta$, or IL-10 by Ehrlich carcinoma cells was enough to prevent the increase of NK activity by the $n$-hexane extract [87].
Ahn et al [88] investigated the beneficial effects of the consumption of an extract of A blazei Murill Kyowa $(\mathrm{ABMK})$ on immunological status and qualities of life in cancer patients undergoing chemotherapy. They observed that NK cell activity was significantly higher in the ABMK-treated group and suggested that ABMK treatment might be beneficial for gyneacological cancer patients undergoing chemotherapy.

The medicinal fungus water extract (FWE) consists of equal amounts of Coriolus versicolor, Cordyceps sinensis, L edodes, A blazei, and G lucidum. Zhang et al [89] reported that FWE enhanced the phagocytosis of peritoneal macrophages, promoted NK activity in mice, and suppressed the growth of B-16 melanoma. FWE had significantly promoted mouse NK activity at the dose of $400 \mathrm{mg} / \mathrm{kg}$, which suggests that FWE may possess the ability to activate NK to directly kill tumor cells, induce NK to secrete cytotoxic agents to elicit the apoptosis of tumor cells, or remove tumor cells by other pathways.

\section{Dendritic cells}

DCs are antigen-presenting cells (APC) with a unique ability to induce primary immune response of both helper $\left(\mathrm{T}_{\mathrm{H}}\right)$ and $\mathrm{T}_{\mathrm{C}}$ [90]. Beside activating naive $\mathrm{T}$ cells, $\mathrm{DCs}$ can directly activate naive and memory B cells. DCs at different stages of differentiation can regulate effectors of innate immunity such as NK cells and NK T cells. The induction of tumor immunity can be initiated by the effectors of innate immunity and further developed by cells of adaptive immunity, with DCs playing a central regulatory role.

Cao and Lin [91] studied the regulatory effects of GlPS, G lucidum polysaccharides (GLPS), on maturation and function of cultured murine bone-marrow-derived DCs in vitro. Gl-PS could promote not only the maturation of cultured murine bone-marrow-derived DCs, but also the immune response initiation induced by DCs.

PL induced maturation of bone-marrow-derived DCs and readies them for T-cell-mediated immune responses. PL significantly increased membrane molecules, including MHC class I, II, CD80, and CD86, and IL-12p70 in DCs. Also, PL markedly reduced the endocytic activity of DCs and augmented their capacity to promote the proliferation of naïve allogeneic T cells [92]. PL enhanced 
the phenotypic and functional maturation of DCs via TLR-2- and/or TLR-4-mediated NF- $\kappa$ B, ERK, and p38 MAPK signal pathways. It is the first article reporting that a polysaccharide from mushrooms can activate a TLR signaling [93]. Kim et al [94] reported that the administration of PL induced antitumor and immunomodulating activities via maturation of $\mathrm{CD} 11 \mathrm{c}^{+} \mathrm{CD} 8^{+} \mathrm{DCs}$ in tumor-bearing mice. The inhibitory effect of PL on the growth of MCA-102 tumor cells was associated with its immunoregulatory properties, including the induction of IL-12 and IFN- $\gamma$ production leading to a $\mathrm{T}_{\mathrm{H}} 1$ dominant state. Therefore, PL would be useful in preventing tumor growth, and it also has the advantage of having no side effects.

The existence of a strongly immunosuppressive state in cancer-bearing individuals inhibits DCs maturation. Kanazawa et al [95] reported that a protein-bound polysaccharide $\mathrm{K}$ (PSK) isolated from the cultured mycelium of $C$ versicolor promoted both the phenotypic and functional maturation of DCs derived from human $\mathrm{CD}_{14}{ }^{+}$mononuclear cells. PSK has also been reported to resolve the immunosuppressive state of a cancer-bearing host and might be associated with DCs maturation directly [95]. Activities of mushroom metabolites on DCs are summarized in Table 4.

\section{Complement}

Activation of complement by either the classical or alternative pathway results in the generation of a wide spectrum of biological activities with the potential to modify immune responses $[96,97]$. Particularly, the activation of complement via the alternative pathway is important in natural immunity to bacterial infections [98, 99].

Although there are a few reports concerning the relationship between complement-activating and tumorregressing activity of glucan including lentinan, the positive correlation between the two activities was found by Okuda et al [100]. They observed a correlation between the ability to activate complement via the alternative pathway in vitro and inhibition of tumor growth in vivo. However, the opposite result, no correlation, was found by Hamuro et al [101]. Thus there is no consistent view on the correlation between the two antagonozing activities.

ABP-F and ABP-M, fine particles of $A$ blazei Murill fruiting body and mycelium, respectively, prepared by mechanical disruption, activated the human complement system via the alternative pathway in human serum (Table 5). When particles from fruiting bodies of A blazei Murill (ABP-F) were reacted with human serum, the formation of complement-opsonized ABP, iC3b-ABP-F complexes, and binding of the complexes to human peripheral blood monocytes, were demonstrated in vitro by immunofluorescence. Further, the resident human peripheral nucleated cells incubated in the presence of $\mathrm{iC} 3 \mathrm{~b}-\mathrm{ABP}-\mathrm{F}$ complexes inhibited the proliferation of the human tumor cell line TPC-1 in vitro [102].
An alkali extract from cultured mycelium of $G l u$ cidum activated both classical and alternative pathways of complement [103]. Min et al [104] reported that triterpenoids such as ganoderiol F, ganodermanondiol, and ganodermanontriol from $G$ lucidum had a potent anticomplement activity against the classical pathway with $\mathrm{IC}_{50}$ values of $4.8-4.17 \mu \mathrm{M}$. A clinical study in elderly patients with insomnia and palpitation has shown that taking Glucidum essence for 4-6 weeks increased their serum C3 levels [105].

Also, LELFD, a $\beta$-( $1 \rightarrow 3)$-glucan, obtained from liquid-cultured mycelium of $G$ frondosa, could activate the alternative complement pathway [106].

Anticomplementary activity of 61 strains of higher fungi from Korea was screened for immunostimulation [107]. Extracts from 11 of 61 strains, including 5 of $G$ lucidum, 3 of L edodes, 2 of Cordyceps sp, and 1 of Agaricus campestris, showed higher anticomplementary activity than Krestin from $C$ versicolor. The most potent anticomplementary activity was found with an extract from $L$ edodes IY105, that reduced complement capacity by $31.7 \%$.

\section{EFFECTS OF MUSHROOM METABOLITES ON ADAPTIVE IMMUNE SYSTEM}

\section{Tlymphocytes}

T lymphocytes include T-helper $\left(\mathrm{T}_{\mathrm{H}}\right)$ cells and cytotoxic $\mathrm{T}\left(\mathrm{T}_{\mathrm{C}}\right)$ cells. $\mathrm{T}_{\mathrm{H}}$ cells interact with $\mathrm{B}$ cells and help them to divide, differentiate, and make antibody or interact with mononuclear phagocytes and help them destroy intracellular pathogens. $\mathrm{T}_{\mathrm{H}}$ cells generate their effects by releasing soluble cytokines and/or by direct cell-cell interactions. The $\mathrm{T}_{\mathrm{C}}$ cells destroy target host cells that have been infected by pathogens.

\section{$T_{H}$ cells}

$\mathrm{CD}^{+}$cells secrete a number of cytokines that are important in the activation of $\mathrm{B}$ and other $\mathrm{T}$ cells, as well as cells of the innate immune system. Based on the types of cytokines these $\mathrm{CD} 4^{+}$cells produce, they are classified into a number of $\mathrm{T}_{\mathrm{H}}$ types $(0,1,2$, or 3$)$. $\mathrm{T}_{\mathrm{H}} 1$ cells produce IL- 2 , IFN- $\gamma$, and TNF- $\beta$ (LT), and introduce cellular immunity to mainly intracellular infections organisms. $\mathrm{T}_{\mathrm{H}} 2$ cells produce IL-4, IL-5, IL-6, IL-10, and IL-13, and activate humoral immunity, mainly directed against extracellular infections. Precursor or $\mathrm{T}_{\mathrm{H}} 0$ cells produce IL-4 and IFN- $\gamma$ concomitantly. Less is known about the physiological role of $\mathrm{T}_{\mathrm{H}} 0$ type cells. Thymus-derived regulatory T-cell populations, including naturally occurring $\mathrm{CD} 4^{+} \mathrm{CD} 25^{+} \mathrm{T}$ cells and inducible IL-10 or TGF- $\beta$ producing $\mathrm{T}_{\mathrm{R}} / \mathrm{T}_{\mathrm{H}} 3$ cells, develop in the periphery from $\mathrm{T}_{\mathrm{H}}$ cells depending on the tolerance-inducing microenvironment in which these T cells reside. By blocking activation of other lymphocytes and APC either directly (by CTLA4-CD28 interaction) or indirectly (by cytokines like IL-10 and TGF- $\beta$ ), these cells ensure self-tolerance mechanisms. In diseased states, however, the presence and/or 
TABLE 4. Immunomodulatory activities of mushroom compounds on DCs.

\begin{tabular}{|c|c|c|c|}
\hline Species & Compound & Immune effects & Reference \\
\hline Glucidum & Gl-PS & $\uparrow$ proliferation of one-way MLC induced by DC & {$[91]$} \\
\hline & & $\begin{array}{l}\uparrow \text { phenotypic and functional maturation of DC } \\
\uparrow \text { membrane molecules, including MHC I, II, CD80, and CD86, and IL-12p70 in DC }\end{array}$ & \\
\hline$P$ linteus & PL & $\begin{array}{l}\downarrow \text { endocytic activity of DC } \\
\uparrow \text { capacity of DC to promote the proliferation of naïve allogenic T cells and } \\
\text { readies them for T-cell-mediated immune responses }\end{array}$ & [92] \\
\hline C versicolor & PSK & $\begin{array}{l}\text { Promoted both the phenotypic and functional maturation of DC derived from } \\
\text { human } \mathrm{CD} 14^{+} \text {mononuclear cells }\end{array}$ & {$[95]$} \\
\hline
\end{tabular}

TABLE 5. Immunomodulatory activities of mushroom compounds on complement.

\begin{tabular}{|c|c|c|c|}
\hline Species & Compound & Immune effects & Reference \\
\hline A blazei & $\begin{array}{l}\text { Fine particles of fruiting body: ABP-F, } \\
\text { and mycelium: ABP-M }\end{array}$ & $\begin{array}{l}\text { Activation of the human complement system via the } \\
\text { alternative pathway in human serum }\end{array}$ & {$[102]$} \\
\hline Glucidum & Alkali extract & $\begin{array}{l}\text { Activation of both classical and alternative pathways of } \\
\text { complement }\end{array}$ & {$[103]$} \\
\hline Glucidum & Triterpenoids & Anticomplement activity & {$[104]$} \\
\hline$G$ frondosa & LELFD & Activation of the alternative complement pathway & {$[106]$} \\
\hline
\end{tabular}

activity of these cells is often reduced leading to enhanced immunopathology, characteristic of chronic inflammatory diseases, like auto-immune and allergic diseases.

The downstream immune response is chosen depending on which subtype of $\mathrm{T}$ cell is activated, which means that the proportion of the activated sub-types influences phylaxis immunity and antitumor immunity. This control system is also affected by the production of IL- $1 \beta$, IL-12, and IL-18 by APC $[108,109]$. The development of $\mathrm{T}_{\mathrm{H}} 1$ or $\mathrm{T}_{\mathrm{H}} 2$ types from naïve cells to effector cells is regulated by the presence of specific cytokines in the microenvironment at the time of $\mathrm{T}$ cell priming. For the $\mathrm{T}_{\mathrm{H}} 1$ type, IL12 is a necessary cytokine of differentiation [110], whereas for the $\mathrm{T}_{\mathrm{H}} 2$ type, IL-4 and IL-10 are critical [111]. Recent study shows that many immune disorders are attributable to the collapse of the system controlling the proportion of $\mathrm{T}_{\mathrm{H}} 1$ to $\mathrm{T}_{\mathrm{H}} 2$ cells [112]. Many diseases such as leprosy, allergy, multiple sclerosis, and responses to immunotoxic agents have pathology associated with aberrant $\mathrm{T}_{\mathrm{H}} 1$ and $\mathrm{T}_{\mathrm{H}} 2$ polarization. $\mathrm{T}_{\mathrm{H}} 1$ cells may cause immunopathology and organ-specific autoimmune disease if dysregulated $[113,114,115,116]$. Because cytokines produced by $\mathrm{T}_{\mathrm{H}} 2$ cells, such as IL-4 and IL-5, can activate mast cells and eosinophils and in addition can result in elevated levels of IgE, they have been strongly implicated in atopy and allergic inflammation [117]. Restoration of the proper balance between $\mathrm{T}_{\mathrm{H}} 1$ and $\mathrm{T}_{\mathrm{H}} 2$ cells is generally considered essential in the treatment of tumors, which are generated when cellular immunity is affected by immunosuppressing factors.

Some mushroom polysaccharides might induce a type 1 immune response, whereas others favor a type 2 polarization $[49,118]$. Borchers et al [49] reported that the lim- ited data available to date do not allow one to determine whether mushroom polysaccharides do so independently of the animal strain or species and disease state investigated or whether the nature of their immunomodulatory effects depends on the model to a greater extent than has been appreciated to date.

Lentinan has been described as a T-cell-oriented adjuvant [119]. The skewing of $\mathrm{T}_{\mathrm{H}} 1 / \mathrm{T}_{\mathrm{H}} 1$ balance to $\mathrm{T}_{\mathrm{H}} 1$ by lentinan (Table 6) is directed through the distinctive production of IL-12 versus IL-6, IL-10, and PGE 2 by peritoneal macrophages, depending on intracellular glutathione redox status [120]. Based on the intracellular content of glutathione, two classes of macrophages have been proposed with diverse functional consequences: reductive macrophages with high, and oxidative macrophages with low glutathione levels.

Sclerotinia sclerotiorum glucan (SSG) from Sclerotinia sclerotiorum IFO 9395 induced the development of $\mathrm{T}_{\mathrm{H}} 1$ cells via the IL-12 pathway [118].

Inoue et al [121] investigated the antitumor functions of D-fraction in relation to its control of the balance between $T$ lymphocyte subsets $\mathrm{T}_{\mathrm{H}} 1$ and $\mathrm{T}_{\mathrm{H}} 2$. Dfraction decreased the activation of $\mathrm{B}$ cells and potentiated the activation of $\mathrm{T}_{\mathrm{H}}$ cells, resulting in enhanced cellular immunity. It also induced the production of IFN$\gamma$, IL-12p70, and IL-18 by whole spleen cells and lymph node cells, but suppressed that of IL-4. These results suggest that $\mathrm{D}$-fraction establishes $\mathrm{T}_{\mathrm{H}} 1$ dominance which induces cellular immunity in the population that was $\mathrm{T}_{\mathrm{H}} 2$ dominated due to the presence of this particular carcinoma [121]. In a later study, Harada et al [122] reported that $\mathrm{D}$-fraction induces the differentiation into $\mathrm{T}_{\mathrm{H}} 1$ cells of $\mathrm{CD} 4^{+} \mathrm{T}$ cells in tumor-bearing BALB/c mice 
TABLE 6. Immunomodulatory activities of mushroom compounds on T cells.

\begin{tabular}{|c|c|c|c|}
\hline Species & Compound & Immune effects & Reference \\
\hline$F$ velutipes & Fve & $\mathrm{T}_{\mathrm{H}} 1$ response & {$[18]$} \\
\hline $\begin{array}{l}\text { S sclerotiorum IFO } \\
9395\end{array}$ & SSG & $\mathrm{T}_{\mathrm{H}} 1$ response & {$[118]$} \\
\hline$L$ edodes & Lentinan & $\mathrm{T}_{\mathrm{H}} 1$ response & {$[120]$} \\
\hline$G$ frondosa & D-fraction & $\begin{array}{l}\text { Enhances } \mathrm{T}_{\mathrm{H}} 1 \text { dominant response through enhancement of } \\
\text { IL-12p70 and IFN- } \gamma \text { produced by activated DCs }\end{array}$ & {$[121,122]$} \\
\hline$V$ volvacea & Vvo & $\begin{array}{l}\uparrow \mathrm{T}_{\mathrm{H}} 1 \text {-specific cytokines (IL-2, IFN- } \gamma, \mathrm{LT} \text { ), } \mathrm{T}_{\mathrm{H}} 2 \text {-specific } \\
\text { cytokine (IL-4), TNF- } \alpha \text {, and IL- } 2 \mathrm{R}\end{array}$ & {$[123,124]$} \\
\hline
\end{tabular}

in which the $\mathrm{T}_{\mathrm{H}} 2$ response was dominant through enhancement of IL-12p70 production by DCs, when the ratio of $\mathrm{CD} 8 \alpha^{+}$DCs to CD $8 \alpha^{-}$DCs increased. In addition, examination of the tumor rejection effect of D-fractionstimulated DCs loaded with tumor antigen revealed that tumor growth is inhibited completely by activating $\mathrm{CD} 4^{+}$ T cells and $\mathrm{CD}^{+} \mathrm{T}$ cells. Furthermore, the level of TNF- $\alpha$, which is produced by activated macrophages and NK cells and is cytotoxic for tumor cells, increased by D-fractionDCs injection, indicating that D-fraction enhanced the protective immunity by DCs loaded with tumor antigen through activating macrophages and NK cells. Although the action of D-fraction on DCs and its intracellular signal transduction pathway remain unclear, Dfraction may be a useful stimulator of DCs, which induce the differentiation of $\mathrm{CD}^{+} \mathrm{T}$ cells to $\mathrm{T}_{\mathrm{H}} 1$ cells [122].

Vvo, a fungal immunomodulatory protein (FIP) purified from the edible mushroom, Volvariella volvacea, induced most $\mathrm{T}_{\mathrm{H}} 1$-specific cytokines (IL- 2, IFN- $\gamma$, and LT) and one $\mathrm{T}_{\mathrm{H}} 2$-specific cytokine (IL-4) within 4 hours in mouse spleen cells. This result indicates that Vvo principally acts on $\mathrm{T}_{\mathrm{H}} 1$ cells and to a lesser extent on $\mathrm{T}_{\mathrm{H}} 2$ cells in the early event of activation. It is known that IL-4 acts on $\mathrm{B}$ cells to induce activation and differentiation, leading in particular to the production of IgE. The lower effect of Vvo compared with other FIPs on the prevention of systemic anaphylaxis may be attributed to the elevated expression of IL-4 [123, 124].

Fve, a FIP isolated from the fruiting body of Flammulina velutipes, selectively stimulates a $\mathrm{T}_{\mathrm{H}} 1$ response in hPBMCs [18]. Recently Hsieh et al [18] have characterized the immunomodulatory effects of Fve in more detail and investigated the prophylactic use of Fve via the oral route in a murine model of food allergy. They have demonstrated that oral administration of Fve during allergen sensitization could induce a $\mathrm{T}_{\mathrm{H}} 1$-predominant allergen-specific immune response in mice and protect the mice from systemic anaphylaxis-like symptoms after subsequent oral challenge with the same allergen. It is worth noting that Fve could be administered orally and retain its activity, while most protein drugs cannot. This characteristic greatly promotes the potential of im- munoprophylactic use of Fve [18]. Liu et al [16, 17] have demonstrated the efficacy of local nasal immunotherapy (LNIT) for group 2 allergen of house dust mite Dermatophagoides-pteronyssinus- (Dp2-) induced airway inflammation in mice, using Dp2 peptide and Fve or LZ8, a FIP isolated from G lucidum.

\section{B cells}

Three polysaccharides isolated from G lucidum, two heteroglycans (PL-1 and PL-4) and one glucan (PL-3) enhanced the proliferation of $\mathrm{T}$ and $\mathrm{B}$ lymphocytes in vitro to varying contents and PL- 1 exhibited an immune stimulating activity in mice [125].

PGL, a complex $\beta$-D-glucan, has a strong effect on suppressing the antibody production [126].

GLIS, a proteoglycan isolated from the fruiting body of G lucidum, is a B-cell stimulating factor. This compound stimulated B lymphocyte activation, proliferation, differentiation and production of immunoglobulins. The activation of B cells by GLIS may be associated with the expression of PKC $\alpha$ and PKC $\gamma$ in B cells [127]. GLIS stimulated the proliferation of mouse spleen lymphocytes, resulting in a threefold to fourfold increase in the percentage of B cells. GLIS also activated mouse spleen lymphocytes, and most of the activated cells were B cells [127].

PL selectively activates murine B cells but not $T$ cells [128]. Since PL cannot penetrate cells due to its large molecular mass (approximately $15 \mathrm{kD}$ ), this selectivity may be caused by the surface binding of this molecule to receptors specifically expressed on B-cells but not on $\mathrm{T}$ cells. The B-cell receptor, BCR, consists of surface immunoglobulin and CD79a-CD79b. Upon BCR ligation, the BCR-associated kinase Lyn phosphorylates CD79aCD79b. In addition, coreceptors such as CD19 and CD38 positively regulate BCR signaling. Complement receptor CD11b-CR3, or Mac-1, is expressed on the surface of macrophages and NK cells and has been identified as the receptor of $\beta$-glucans [129]. Although PL and $\beta$-glucans show different specificities on B and T cells, they may use the same receptor on B cells. A further complete investigation of the membrane receptors of PL should shed light on its selectivity for B cells. 
TABLE 7. Immunomodulatory activities of mushroom compounds on B cells.

\begin{tabular}{llll}
\hline Species & Compound & Immune effects & Reference \\
\hline Glucidum & PL-1, PL-3, PL-4 & $\uparrow$ T and B lymphocytes proliferation & [125] \\
Glucidum & PGL & $\uparrow$ antibodies & $\downarrow$ antibody production \\
& GLIS & $\uparrow$ proliferation of mouse spleen lymphocytes & {$[126]$} \\
Glucidum & proteoglycan & $\uparrow$ B lymphocyte activation, proliferation, and differentiation & and production of immunoglobulins \\
Plinteus & PL & $\uparrow$ murine splenic lymphocytes and activation of B cells & {$[127]$} \\
Glucidum & LZ-8 & $\downarrow$ antibody production & {$[128]$} \\
F velutipes & Fve & $\downarrow$ antibody production & {$[130]$} \\
\hline
\end{tabular}

Evidence that FIPs suppress antibody production came from the result that the proportion of Arthus reaction-positive mice was reduced to $40 \%$ by LZ-8 [130]. Fve also suppressed antibody production as demonstrated by its effect in the hind paw edema test but the inhibition was not complete [131]. Activities are summarized in Table 7 .

Figure 3 summarizes the targets for interaction between mushroom ingredients and various components of the adaptive immune system.

\section{RECOGNITION AND RECEPTORS}

\section{Evidence for $\beta$-glucan receptor binding of immune cells}

The innate immune system is the first line of defense against microbial invasion, and must immediately recognize and counter infections while the slower, more specific, adaptive response is mounted. The innate cellular response is comprised principally of phagocytic cells and is dependent on germline encoded receptors which recognize conserved microbial structures. The innate immune system identifies infectious agents or compounds by means of pattern-recognition receptors (PRR). These receptors recognize pathogen-specific macromolecules called pathogen-associated molecular patterns (PAMP).

Polysacharides cannot penetrate cells due to their large molecular mass, so the first step in the modulation of cellular activity is binding to immune cell receptors. Among all the immunomodulatory metabolites isolated from mushrooms, glucans and in particular $\beta$-glucans have been studied profoundly to identify its target receptor in immune cells. It has been postulated that glucans are fungal pattern-recognition molecules for the innate immune system $[132,133]$. The mechanisms by which the innate immune system recognizes and responds to fungal cell wall carbohydrate is a very complex and multifactorial process [134]. The various activities of $\beta$-glucans may reflect the presence of multiple cellular targets or receptors [135]. To date several $\beta$-glucan receptors have been identified as candidates mediating these activities [136], namely, complement receptor 3 (CR3, $\alpha_{\mathrm{M}} \beta_{2}$ integrin, or
CD11b/CD18) [137], lactosylceramide [138], scavengers receptors [139], dectin-1 [140], and toll-like receptors TLR-2 and TLR-4 [141].

Dectin-1 is broadly expressed, with highest surface expression on populations of myeloid cells (monocyte/macrophage and neutrophil lineages) in the blood, bone marrow and spleen. DCs, and a sub-population of $\mathrm{T}$ cells, also expressed dectin-1 but at lower levels [142]. It is plausible that the expression of dectin-1, as a T-cell binding receptor, on a subset of T-cells may be part of a novel mechanism for the regulation of the $\mathrm{T}$ cell response by specific subsets of T cells as well as by APC [143].

Recently, Kim et al [93] have shown that PL, proteoglycan isolated from $P$ linteus, could induce the phenotypic and functional maturation of DCs via TLR-2 and/or TLR-4. Shao et al [141] suggested that TLR-4 is also involved in GLPS-mediated macrophage activation. Rat antimouse TLR-4 monoclonal antibody $(\mathrm{AB})$ inhibited the proliferation of BALB/c mouse B cells under GLPS stimulation. Combination of Abs against mouse TLR-4 and immunoglobulin achieved almost complete inhibition of GLPS-induced B-cell proliferation, implying that both membrane Ig abd TLR-4 are required for GLPS-mediated $B$ cell activation.

Lowe et al [134] reported that a $\beta$-D- $(1 \rightarrow 3)$ - linked glucan polymer composed of seven glucose subunits is the minimum binding ligand for glucan PRR on a human monocyte cell line and indicated that all available monocyte glucan receptors will recognize the basic $\beta$ $D$ - $(1 \rightarrow 3)$-glucan structure with approximately the same affinity. However, as the glucan polymer becomes more complex it appears to be preferentially recognized by one glucan receptor versus another.

Additional studies are required to determine which receptor(s) are essential to the expression of the various immunobiological effects ascribed to $\beta$-glucans. The intracellular events that occur after glucan-receptor binding have not been fully determined. As long as it remains unclear what receptors are involved in and what downstream events are triggered by the binding of these glucans to their target cells, it will be difficult to make further progress in understanding their biological activities. 


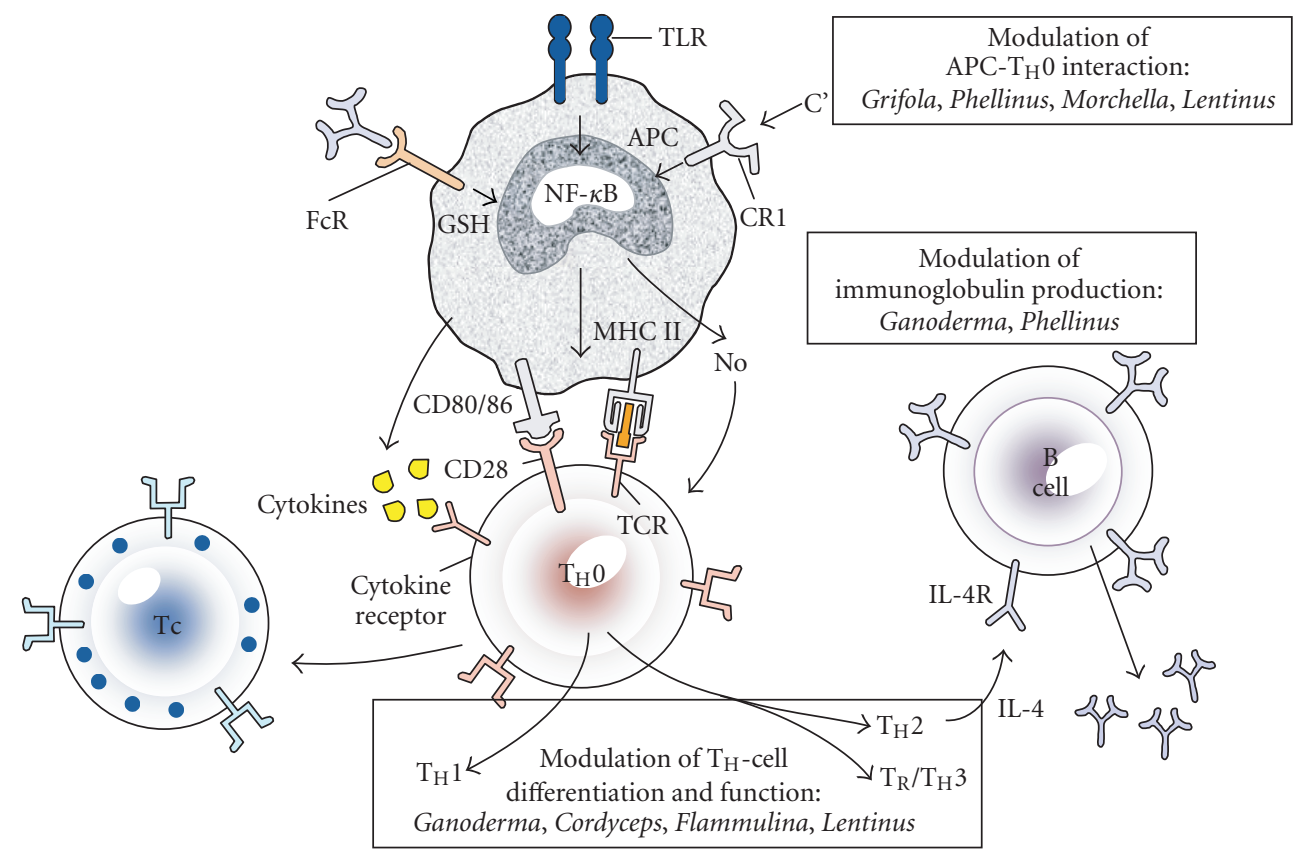

FIGURE 3. Schematic representation of the possible targets of the adaptive immune system for mushroom ingredients with immunomodulatory properties. APC: antigen-presenting cell; FcR: Fc receptor; TLR: Toll-like receptor; CR1: complement receptor type 1; C': activated complement; GSH: glutathione; MHC II: major histocompatibility complex class II; TCR: T-cell receptor; $\mathrm{T}_{\mathrm{H}}$ : helper T cells; $\mathrm{T}_{\mathrm{C}}$ : cytotoxic $\mathrm{T}$ lymphocytes; $\mathrm{T}_{\mathrm{R}}$ : regulatory $\mathrm{T}$ cells; NO: nitric oxide; IL-4: interleukin-4; IL-4R: interleukin-4 receptor; CD: cluster designation.

\section{CONCLUSIONS}

The information presented here illustrates the distinct immunomodulatory properties associated with mushroom constituents. The discovery and identification of new safe drugs, without severe side effects, has become an important goal of research in the biomedical science. Medicinal effects have been demonstrated for many traditionally used mushrooms, with large differences in immunomodulatory properties. The species studied so far represent a vast source of immunomodulating and antitumor extracts and metabolites. Thus, the biochemical mechanisms that mediate the biological activity are still not clearly understood. Mushroom metabolites are known to stimulate different cells of the immune system. The major immunopotentiation effects of these active substances include mitogenicity, stimulation of hematopoietic stem cells, activation of alternative complement pathway, and activation of immune cells, such as $\mathrm{T}_{\mathrm{H}}$ cells, Tc cells, B cells, macrophages, DCs, and NK cells.

Different profiles have been observed in relation to the activated immune cells, for example, GLPS activate mouse B cells and macrophages but not $T$ cells [141], polysaccharides from $P$ linteus can stimulate $B$ cells, $T$ cells, and macrophages [144], while lentinan is a stimulator of T cells and macrophages, but not B cells [145]. Some of them might promote a $\mathrm{T}_{\mathrm{H}} 1$ response and others a $\mathrm{T}_{\mathrm{H}} 2$ response [49]. In the particular case of glu- cans, despite the structural and functional similarities of some of them, they differ in their ability to elicit various cellular responses, particularly cytokine expression and production and in their effectiveness against specific tumors [5]. The relationship between polysaccharide origin, structure, and their immunomodulation activity remains to be further characterized $[125,146]$.

Mushroom products are obvious immunoenhancers that potentiate the immune system in multiple ways. Mushroom polysaccharides are among the emerging new agents that could directly support or enhance functional autologous hematopoietic stem cell recovery [61]. In preventive medicine, defense against invasion by foreign bodies is dependent on enhancing the natural immune system, including activation of macrophages and NK cells. Macrophages stimulated by mushroom products release several inflammatory cytokines, IL-1, IL-6, IL-8, TNF$\alpha$, and NO, all of which directly induce tumoricidal activity in macrophages. Macrophages produce also IL- $1 \beta$, IL-10, IL-12, GM-CSF, and IL-18. In other cases mushroom extracts inhibit the production of $\mathrm{NO}, \mathrm{PGE}_{2}$, IL$1 \beta$, and TNF- $\alpha$ in LPS-stimulated macrophages and LPSadminister mice. This antiinflammatory effect occurs by down regulation of iNOS, COX-2, IL- $1 \beta$, and TNF- $\alpha$ gene expression via the suppression of NF- $\kappa \mathrm{B}$ activation. Thus, these mushroom extracts might be relevant for clinical use for inflammatory diseases, including endotoxemia or sepsis. Some mushroom metabolites like D-fraction 
represent an important biological response modifier (BRM) due to the enhancement of NK cells activity in cancer patients. Mushroom polysaccharides induce regulatory effects on maturation and function of DCs and consequently enhance the capacity of DCs to promote the proliferation of naïve allogenic $\mathrm{T}$ cells and readies them for T-cell-mediated immune responses. Both classical and alternative pathways of complement have been activated by mushrooms and also anticomplementary activity has been detected in different mushrooms. T and B lymphocytes are also activated by mushrooms. Some mushroom polysaccharides stimulate the production of antibodies but others as PGL have a strong effect on suppressing the antibody production [126].

The immunomodulating action of mushroom metabolites is specially valuable as a means of prophylaxis, a mild and noninvasive form of treatment, prevention of metastatic tumors, and as a cotreatment with chemotherapy [4]. The enhancement or potentiation of host defense mechanisms has been recognized as a possible means of inhibiting tumor growth without harming the host, but other alternative mechanisms are possible, like targeting the ras-mediated signaling pathway [147]. Whether certain metabolites enhance or suppress immune responses can depend on a number of factors, including dose, route of administration, and timing of administrations of the compound in question. The type of activity these metabolites exhibit can also depend on their mechanism of action or the site of activity. Taken together, the present data suggest that mushroom extracts or metabolites should be selected and used properly for modulation of immune responses. Due to the differences in activities among various extracts and isolated metabolites, it is imperative to evaluate its biological properties before any suggestions for use of a particular product in clinical practice. For example, D-fraction enhanced rather than suppressed the development of collagen-induced arthritis (CIA) [148]. Administration of D-fraction stimulates immune function of normal and tumor-bearing mice [84]. GLIS from $G$ lucidum has an effect on lymphocytes or purified $\mathrm{B}$ cells from tumor-bearing mice markedly stronger than on lymphocytes or purified B cells from normal mice [127]. It has also been reported that an extract from the deep layer of cultivated mycelia of the Cov-1 strain of $C$ versicolor enhances the immune functions in old mice but not in young mice [149].

For some of the mushroom metabolites described, further research is needed to determine whether there are any in vivo benefits comparable to the in vitro effects reported. Although it is unlikely that high molecular weight polysaccharidse would be absorbed after oral administration, it is possible that it could exert a therapeutic effect by direct interaction with the mucosal immune system of the gastrointestinal tract. Thus, they could be developed as a preparation for use as a dietary supplement or pharmaceutical.
Some mushroom metabolites, such as the glucans lentinan and schizophyllan, or the polysaccharide-protein PSK, and the PSP, are used clinically for immune therapy $[150,151,152,153]$ and have been developed as pharmaceuticals in Japan and are now commercially available worldwide. PSK was commercialized by Kureha Chemicals, Japan. After extensive clinical trials, PSK was approved for use in Japan in 1977, and by 1985, it ranked 19th on the list of the world's commercially most successful drugs [154]. Annual Japanese sales of PSK in 1987 were worth US $\$ 357$ million [154]. About 10 years after PSK, PSP appeared on the market. Both compounds have been isolated from $C$ versicolor. In addition to clinically tested PSK and PSP, numerous other extract preparations of $C$ versicolor are on the market as neutraceuticals and traditional medicines. Neutraceutical PSP preparations are sold worldwide in the form of capsules, ground biomass tablets, syrups, food additives, and teas [153].

Quality control of mushrooms poses significant challenges: small differences in genetics, soil, temperature, moisture, and time of harvesting can lead to significant differences in the concentration of important constituents. The cultivation of mushrooms to produce fruiting bodies is a long-term process requiring from one to several months for the first fruiting bodies to appear. Nowadays, more research is carried out in relation to submerged culture. Submerged culture has potential advantages for higher mycelial production in a compact space and for a shorter incubation time with a lesser chance of contamination. Further optimization of the culture medium composition and physicochemical conditions of growth allows regulation of fungal metabolism in order to obtain standardized nutriceutical substances in higher yield. Mycelia formed by growing pure cultures in submerged culture is the best technique for obtaining consistent and safe mushroom products $[3,12,155]$. Mushrooms are still far from being thoroughly studied.

\section{ACKNOWLEDGMENT}

The authors acknowledge the financial support of the Valencian authorities (Generalitat Valenciana; CTBPDC/2003/014) for Cristina Lull.

\section{REFERENCES}

[1] Chang R. Functional properties of edible mushrooms. Nutr Rev. 1996;54(pt 2):S91-S93.

[2] Wasser SP, Weis AL. Therapeutic effects of substances occurring in higher basidiomycetes mushrooms: a modern perspective. Crit Rev Immunol. 1999;19(1):65-96.

[3] Reshetnikov SV, Wasser SP, Tan KK. Higher basidiomycota as a source of antitumor and immunostimulating polysaccharides. Int J Med Mushr. 2001;3(4):361-394. 
[4] Wasser SP. Medicinal mushrooms as a source of antitumor and immunomodulating polysaccharides. Appl Microbiol Biotechnol. 2002;60(3):258-274.

[5] Borchers AT, Stern JS, Hackman RM, Keen CL, Gershwin ME. Mushrooms, tumors, and immunity. Proc Soc Exp Biol Med. 1999;221(4):281-293.

[6] Manzi P, Gambelli L, Marconi S, Vivanti V, Pizzoferrato L. Nutrients in edible mushrooms: an inter-species comparative study. Food Chem. 1999;65:477-482.

[7] Mattila P, Suonpaa K, Piironen V. Functional properties of edible mushrooms. Nutrition. 2000;16(78):694-696.

[8] Smith JE, Rowan NJ, Sullivan R. Medicinal mushrooms: a rapidly developing area of biotechnology for cancer therapy and other bioactivities. Biotechnol Lett. 2002;24(22):1839-1845.

[9] Gao Y, Chan E, Zhou S. Immunomodulating activities of Ganoderma, a mushroom with medicinal properties. Food Rev Int. 2004;20:123-161.

[10] Breene WM. Nutritional and medicinal value of specialty mushrooms. J Food Prot. 1990;53(10):883-894.

[11] Chang ST. World production of cultivated edible and medicinal mushrooms in 1997 with emphasis on Lentinus edodes (Berk) Sing in China. Int J Med Mushr. 1999;1:291-300.

[12] Wasser SP, Nevo E, Sokolov D, Reshetnikov S, Timor-Tismenetsky M. Dietary supplements from medicinal mushrooms: diversity of types and variety of regulations. Int J Med Mushr. 2000;2(1):1-19.

[13] Hobbs C, LAc. Medicinal Mushrooms: An Exploration of Tradition, Healing and Culture. Santa Cruz, Calif: Botanica Press; 1995.

[14] Hobbs C. Medicinal value of Lentinus edodes (Berk) Sing (Agaricomycetideae). A literature review. Int J Med Mushr. 2000;2(4):287-302.

[15] Li XM, Huang CK, Zhang TF, et al. The Chinese herbal medicine formula MSSM-002 suppresses allergic airway hyperreactivity and modulates TH1/TH2 responses in a murine model of allergic asthma. J Allergy Clin Immunol. 2000;106(4):660668.

[16] Liu YH, Kao MC, Lai YL, Tsai JJ. Efficacy of local nasal immunotherapy for Dp2-induced airway inflammation in mice: using Dp2 peptide and fungal immunomodulatory peptide. J Allergy Clin Immunol. 2003;112(2):301-310.

[17] Liu YH, Tsai CF, Kao MC, Lai YL, Tsai JJ. Effectiveness of Dp2 nasal therapy for Dp2- induced airway inflammation in mice: using oral Ganoderma lucidum as an immunomodulator. J Microbiol Immunol Infect. 2003;36(4):236-242.

[18] Hsieh KY, Hsu CI, Lin JY, Tsai CC, Lin RH. Oral administration of an edible-mushroom-derived protein inhibits the development of food-allergic reactions in mice. Clin Exp Allergy. 2003;33(11):15951602.
[19] Li XM, Zhang TF, Huang CK, et al. Food allergy herbal formula-1 (FAHF-1) blocks peanut-induced anaphylaxis in a murine model. J Allergy Clin Immunol. 2001;108(4):639-646.

[20] Kuo YC, Huang YL, Chen CC, Lin YS, Chuang KA, Tsai WJ. Cell cycle progression and cytokine gene expression of human peripheral blood mononuclear cells modulated by Agaricus blazei. J Lab Clin Med. 2002;140(3):176-187.

[21] Jose N, Ajith TA, Janardhanan KK. Methanol extract of the oyster mushroom, Pleurotus florida, inhibits inflammation and platelet aggregation. Phytother Res. 2004;18(1):43-46.

[22] Kim SH, Song YS, Kim SK, Kim BC, Lim CJ, Park EH. Anti-inflammatory and related pharmacological activities of the $\mathrm{n}-\mathrm{BuOH}$ subfraction of mushroom Phellinus linteus. J Ethnopharmacol. 2004;93(1):141-146.

[23] Kim GY, Kim SH, Hwang SY, et al. Oral administration of proteoglycan isolated from Phellinus linteus in the prevention and treatment of collagen-induced arthritis in mice. Biol Pharm Bull. 2003;26(6):823-831.

[24] Bobek P, Galbavy S. Hypocholesterolemic and antiatherogenic effect of oyster mushroom (Pleurotus ostreatus) in rabbits. Nahrung. 1999;43(5):339-342.

[25] Yamada T, Oinuma T, Niihashi $M$, et al. Effects of Lentinus edodes mycelia on dietary-induced atherosclerotic involvement in rabbit aorta. $J$ Atheroscler Thromb. 2002;9(3):149-156.

[26] Gray AM, Flatt PR. Insulin-releasing and insulinlike activity of Agaricus campestris (mushroom). J Endocrinol. 1998;157(2):259-266.

[27] Yoon SJ, Yu MA, Pyun YR, et al. The nontoxic mushroom Auricularia auricula contains a polysaccharide with anticoagulant activity mediated by antithrombin. Thromb Res. 2003;112(3):151-158.

[28] Nanba H, Kodama N, Schar D, Turner D. Effects of Maitake (Grifola frondosa) glucan in HIV-infected patients. Mycoscience. 2000;41:293-295.

[29] Ngai PH, Ng TB. Lentin, a novel and potent antifungal protein from Shiitake mushroom with inhibitory effects on activity of human immunodeficiency virus-1 reverse transcriptase and proliferation of leukemia cells. Life Sci. 2003;73(26):33633374.

[30] Kodama N, Yamada M, Nanba H. Addition of Maitake D-fraction reduces the effective dosage of vancomycin for the treatment of Listeria-infected mice. Jpn J Pharmacol. 2001;87(4):327-332.

[31] Markova N, Kussovski V, Drandarska I, Nikolaeva S, Georgieva N, Radoucheva T. Protective activity of lentinan in experimental tuberculosis. Int Immunopharmacol. 2003;3(10-11):1557-1562.

[32] Kim GY, Roh SI, Park SK, et al. Alleviation of experimental septic shock in mice by acidic polysaccharide isolated from the medicinal mushroom 
Phellinus linteus. Biol Pharm Bull. 2003;26(10): 1418-1423.

[33] Kidd PM. The use of mushroom glucans and proteoglycans in cancer treatment. Altern Med Rev. 2000;5(1):4-27.

[34] Ohno N, Miura NN, Nakajima M, Yadomae T. Antitumor 1,3- $\beta$-glucan from cultured fruit body of Sparassis crispa. Biol Pharm Bull. 2000;23(7):866872.

[35] Ohno N, Furukawa M, Miura NN, Adachi Y, Motoi $\mathrm{M}$, Yadomae T. Antitumor $\beta$-glucan from the cultured fruit body of Agaricus blazei. Biol Pharm Bull. 2001;24(7):820-828.

[36] Fisher M, Yang LX. Anticancer effects and mechanisms of polysaccharide-K (PSK): implications of cancer immunotherapy. Anticancer Res. 2002;22(3):1737-1754.

[37] Mahajan RG, Patil SI, Mohan DR, Shastry P. Pleurotus eous mushroom lectin (PEL) with mixed carbohydrate inhibition and antiproliferative activity on tumor cell lines. J Biochem Mol Biol Biophys. 2002;6(5):341-345.

[38] Ng ML, Yap AT. Inhibition of human colon carcinoma development by lentinan from Shiitake mushrooms (Lentinus edodes). J Altern Complement Med. 2002;8(5):581-589.

[39] Gao Y, Zhou S, Jiang W, Huang M, Dai X. Effects of ganopoly (a Ganoderma lucidum polysaccharide extract) on the immune functions in advanced-stage cancer patients. Immunol Invest. 2003;32(3):201-215.

[40] Gao YH, Zhou SF. Cancer prevention and treatment by Ganoderma, a mushroom with medicinal properties. Food Rev Int. 2003;19:275-325.

[41] Kodama N, Komuta K, Nanba H. Effect of Maitake (Grifola frondosa) D-fraction on the activation of NK cells in cancer patients. J Med Food. 2003;6(4):371-377.

[42] Lee IS, Nishikawa A. Polyozellus multiplex, a Korean wild mushroom, as a potent chemopreventive agent against stomach cancer. Life Sci. 2003;73(25):3225-3234.

[43] Lee YL, Kim HJ, Lee MS, et al. Oral administration of Agaricus blazei (H1 strain) inhibited tumor growth in a sarcoma 180 inoculation model. Exp Anim. 2003;52(5):371-375.

[44] Monro JA. Treatment of cancer with mushroom products. Arch Environ Health. 2003;58(8):533537.

[45] Peng YF, Zhang L, Zeng FB, Xu YX. Structure and antitumor activity of extracellular polysaccharides from mycelium. Carbohyd Polym. 2003;54(3):297303.

[46] Shin KH, Lim SS, Lee S, Lee YS, Jung SH, Cho SY. Anti-tumour and immuno-stimulating activities of the fruiting bodies of Paecilomyces japonica, a new type of Cordyceps spp. Phytother Res. 2003;17(7):830-833.
[47] Sliva D. Ganoderma lucidum (Reishi) in cancer treatment. Integr Cancer Ther. 2003;2(4):358-364.

[48] Tsang KW, Lam CL, Yan C, et al. Coriolus versicolor polysaccharide peptide slows progression of advanced non-small cell lung cancer. Respir Med. 2003;97(6):618-624.

[49] Borchers AT, Keen CL, Gershwin ME. Mushrooms, tumors, and immunity: an update. Exp Biol Med (Maywood). 2004;229(5):393-406.

[50] Hattori TS, Komatsu N, Shichijo S, Itoh K. Proteinbound polysaccharide $\mathrm{K}$ induced apoptosis of the human Burkitt lymphoma cell line, Namalwa. Biomed Pharmacother. 2004;58(4):226-230.

[51] Ho JC, Konerding MA, Gaumann A, Groth M, Liu WK. Fungal polysaccharopeptide inhibits tumor angiogenesis and tumor growth in mice. Life Sci. 2004;75(11):1343-1356.

[52] Jiang J, Slivova V, Harvey K, Valachovicova T, Sliva D. Ganoderma lucidum suppresses growth of breast cancer cells through the inhibition of Akt/NF- $\kappa \mathrm{B}$ signaling. Nutr Cancer. 2004;49(2):209-216.

[53] Jiang J, Slivova V, Valachovicova T, Harvey K, Sliva D. Ganoderma lucidum inhibits proliferation and induces apoptosis in human prostate cancer cells PC-3. Int J Oncol. 2004;24(5):1093-1099.

[54] Nakamura T, Matsugo S, Uzuka Y, Matsuo S, Kawagishi H. Fractionation and anti-tumor activity of the mycelia of liquid-cultured Phellinus linteus. Biosci Biotechnol Biochem. 2004;68(4):868-872.

[55] Shibata Y, Kurita S, Okugi H, Yamanaka H. Dramatic remission of hormone refractory prostate cancer achieved with extract of the mushroom, Phellinus linteus. Urol Int. 2004;73(2):188-190.

[56] Chirigos MA. Immunomodulators: current and future development and application. Thymus. 1992;19 (suppl 1) :S7-S20.

[57] Masihi KN. Immunomodulatory agents for prophylaxis and therapy of infections. Int J Antimicrob Agents. 2000;14(3):181-191.

[58] Jong SC, Birmingham JM. Medicinal benefits of the mushroom Ganoderma. Adv Appl Microbiol. 1992;37:101-134.

[59] Badger AM. Development in industrial microbiology. In: Saratosa FL, Nash CH, Underkofler LA, eds. Proceedings of the Fortieth General Meeting of the Society for Industrial Microbiology. Arlington, Va; 1983:274.

[60] Vickers A. Botanical medicines for the treatment of cancer: rationale, overview of current data, and methodological considerations for phase I and II trials. Cancer Invest. 2002;20(7-8):1069-1079.

[61] Lin H, She YH, Cassileth BR, Sirotnak F, Cunningham Rundles S. Maitake beta-glucan MDfraction enhances bone marrow colony formation and reduces doxorubicin toxicity in vitro. Int Immunopharmacol. 2004;4(1):91-99. 
[62] Jin M, Jung HJ, Choi JJ, et al. Activation of selective transcription factors and cytokines by watersoluble extract from Lentinus lepideus. Exp Biol Med (Maywood). 2003;228(6):749-758.

[63] Jin M, Jeon H, Jung HJ, et al. Enhancement of repopulation and hematopoiesis of bone marrow cells in irradiated mice by oral administration of PG101, a water-soluble extract from Lentinus lepideus. Exp Biol Med (Maywood). 2003;228(6):759766.

[64] Harada T, Miura N, Adachi Y, Nakajima M, Yadomae T, Ohn N. Effect of SCG, 1,3- $\beta$-D-glucan from Sparassis crispa on the hematopoietic response in cyclophosphamide induced leukopenic mice. Biol Pharm Bull. 2002;25(7):931-939.

[65] Sorimachi K, Akimoto K, Ikehara Y, Inafuku K, Okubo A, Yamazaki S. Secretion of TNF- $\alpha$, IL8 and nitric oxide by macrophages activated with Agaricus blazei Murill fractions in vitro. Cell Struct Funct. 2001;26(2):103-108.

[66] Wang SY, Hsu ML, Hsu HC, et al. The anti-tumor effect of Ganoderma lucidum is mediated by cytokines released from activated macrophages and $\mathrm{T}$ lymphocytes. Int J Cancer. 1997;70(6):699-705.

[67] Adachi Y, Okazaki M, Ohno N, Yadomae T. Enhancement of cytokine production by macrophages stimulated with $(1 \rightarrow 3)-\beta$-D-glucan, grifolan (GRN), isolated from Grifola frondosa. Biol Pharm Bull. 1994;17(12):1554-1560.

[68] Okazaki M, Adachi Y, Ohno N, Yadomae T. Structure-activity relationship of $(1 \rightarrow 3)$-beta-Dglucans in the induction of cytokine production from macrophages, in vitro. Biol Pharm Bull. 1995;18(10):1320-1327.

[69] Ishibashi K, Miura NN, Adachi Y, Ohno N, Yadomae T. Relationship between solubility of grifolan, a fungal 1,3- $\beta$-D-glucan, and production of tumor necrosis factor by macrophages in vitro. Biosci Biotechnol Biochem. 2001;65(9):1993-2000.

[70] Sanzen I, Imanishi N, Takamatsu N, et al. Nitric oxide-mediated antitumor activity induced by the extract from Grifola frondosa (Maitake mushroom) in a macrophage cell line, RAW264.7. J Exp Clin Cancer Res. 2001;20(4):591-597.

[71] Duncan CJ, Pugh N, Pasco DS, Ross SA. Isolation of a galactomannan that enhances macrophage activation from the edible fungus Morchella esculenta. J Agric Food Chem. 2002;50(20):5683-5685.

[72] Han SB, Lee CW, Jeon YJ, et al. The inhibitory effect of polysaccharides isolated from Phellinus linteus on tumor growth and metastasis. Immunopharmacology. 1999;41(2):157-164.

[73] Kim GY, Oh YH, Park YM. Acidic polysaccharide isolated from Phellinus linteus induces nitric oxide-mediated tumoricidal activity of macrophages through protein tyrosine kinase and protein kinase C. Biochem Biophys Res Commun. 2003;309(2):399-407.
[74] Kim KM, Kwon YG, Chung HT, et al. Methanol extract of Cordyceps pruinosa inhibits in vitro and in vivo inflammatory mediators by suppressing NF- $\kappa \mathrm{B}$ activation. Toxicol Appl Pharmacol. 2003;190(1):1-8.

[75] Mizuno M, Shiomi Y, Minato K, Kawakami S, Ashida H, Tsuchida H. Fucogalactan isolated from Sarcodon aspratus elicits release of tumor necrosis factor- $\alpha$ and nitric oxide from murine macrophages. Immunopharmacology. 2000;46(2):113-121.

[76] Kurashige S, Akuzawa Y, Endo F. Effects of Lentinus edodes, Grifola frondosa and Pleurotus ostreatus administration on cancer outbreak, and activities of macrophages and lymphocytes in mice treated with a carcinogen, N-butyl-Nbutanolnitrosoamine. Immunopharmacol Immunotoxicol. 1997;19(2):175-183.

[77] Ngai PH, Wang HX, Ng TB. Purification and characterization of a ubiquitin-like peptide with macrophage stimulating, antiproliferative and ribonuclease activities from the mushroom Agrocybe cylindracea. Peptides. 2003;24(5):639-645.

[78] Wang HX, Ng TB, Ooi VE, Liu WK, Chang ST. Actions of lectins from the mushroom Tricholoma mongolicum on macrophages, splenocytes and lifespan in sarcoma-bearing mice. Anticancer Res. 1997;17(1A):419-424.

[79] Miller JS. Biology of natural killer cells in cancer and infection. Cancer Invest. 2002;20(3):405-419.

[80] Sepulveda C, Puente J. Natural killer cells and the innate immune system in infectious pathology. Rev Med Chil. 2000;128(12):1361-1370.

[81] Yokoyama WM, Kim S, French AR. The dynamic life of natural killer cells. Annu Rev Immunol. 2004;22:405-429.

[82] Kodama N, Komuta K, Sakai N, Nanba H. Effects of D-fraction, a polysaccharide from Grifola frondosa on tumor growth involve activation of NK cells. Biol Pharm Bull. 2002;25(12):1647-1650.

[83] Kodama N, Kakuno T, Nanba H. Stimulation of the natural immune system in normal mice by polysaccharide from Maitake mushroom. Mycoscience. 2003;44(3):257-261.

[84] Kodama N, Murata Y, Nanba H. Administration of a polysaccharide from Grifola frondosa stimulates immune function of normal mice. J Med Food. 2004;7(2):141-145.

[85] Takimoto H, Wakita D, Kawaguchi K, Kumazawa Y. Potentiation of cytotoxic activity in naive and tumor-bearing mice by oral administration of hotwater extracts from Agaricus brazei fruiting bodies. Biol Pharm Bull. 2004;27(3):404-406.

[86] Emtage PC, Clarke D, Gonzalo-Daganzo R, Junghans RP. Generating potent Th1/Tc1 T cell adoptive immunotherapy doses using human IL-12: harnessing the immunomodulatory potential of 
IL-12 without the in vivo-associated toxicity [published correction appears in J Immunother]. J Immunother. 2003;26(2):97-106. 2003;26(3):290.

[87] Kaneno R, Fontanari LM, Santos SA, Di Stasi LC, Rodrigues Filho E, Eira AF. Effects of extracts from Brazilian sun-mushroom (Agaricus blazei) on the NK activity and lymphoproliferative responsiveness of Ehrlich tumor-bearing mice. Food Chem Toxicol. 2004;42(6):909-916.

[88] Ahn WS, Kim DJ, Chae GT, et al. Natural killer cell activity and quality of life were improved by consumption of a mushroom extract, Agaricus blazei Murill Kyowa, in gynecological cancer patients undergoing chemotherapy. Int J Gynecol Cancer. 2004;14(4):589-594.

[89] Zhang W, Wang Y, Hou Y. Effects of Chinese medicinal fungus water extract on tumor metastasis and some parameters of immune function. Int Immunopharmacol. 2004;4(3):461-468.

[90] Banchereau J, Briere F, Caux C, et al. Immunobiology of dendritic cells. Annu Rev Immunol. 2000;18:767-811.

[91] Cao LZ, Lin ZB. Regulation on maturation and function of dendritic cells by Ganoderma lucidum polysaccharides. Immunol Lett. 2002;83(3):163169.

[92] Park SK, Kim GY, Lim JY, et al. Acidic polysaccharides isolated from Phellinus linteus induce phenotypic and functional maturation of murine dendritic cells. Biochem Biophys Res Commun. 2003;312(2):449-458.

[93] Kim GY, Han MG, Song YS, et al. Proteoglycan isolated from Phellinus linteus induces toll-like receptors 2- and 4-mediated maturation of murine dendritic cells via activation of ERK, p38, and NFkappaB. Biol Pharm Bull. 2004;27(10):1656-1662.

[94] Kim GY, Oh WK, Shin BC, et al. Proteoglycan isolated from Phellinus linteus inhibits tumor growth through mechanisms leading to

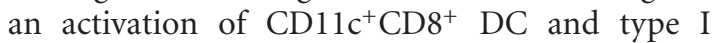
helper T cell-dominant immune state. FEBS Lett. 2004;576(3):391-400.

[95] Kanazawa M, Mori Y, Yoshihara K, et al. Effect of PSK on the maturation of dendritic cells derived from human peripheral blood monocytes. Immunol Lett. 2004;91(2-3):229-238.

[96] Di Luzio NR. Update on the immunomodulating activities of glucans. Springer Semin Immunopathol. 1985;8(4):387-400.

[97] Ross GD, Vetvicka V, Yan J, Xia Y, Vetvickova J. Therapeutic intervention with complement and beta-glucan in cancer. Immunopharmacology. 1999;42(1-3):61-74.

[98] Alper CA, Abramson N, Johnston RB Jr, Jandl JH, Rosen FS. Increased susceptibility to infection associated with abnormalities of complement-mediated functions and of the third component of complement (C3). N Engl J Med. 1970;282(7):350-354.
[99] Winkelstein JA, Smith MR, Shin HS. The role of C3 as an opsonin in the early stages of infection. Proc Soc Exp Biol Med. 1975;149(2):397-401.

[100] Okuda T, Yoshioka Y, Ikekawa T, Chihara G, Nishioka K. Anticomplementary activity of antitumor polysaccharides. Nature: New Biol. 1972;238(12):59-60.

[101] Hamuro J, Hadding U, Bitter-Suermann D. Solid phase activation of alternative pathway of complement by beta-1,3-glucans and its possible role for tumor regressing activity. Immunology. 1978;34(4):695-705.

[102] Shimizu S, Kitada H, Yokota H, et al. Activation of the alternative complement pathway by Agaricus blazei Murill. Phytomedicine. 2002;9(6):536-545.

[103] Lee JW, Chung CH, Jeong H, Lee KH. Effects of alkali extract of Ganoderma lucidum IY007 on complement system. Korean J Mycol. 1990;18:137-144.

[104] Min BS, Gao JJ, Hattori M, Lee HK, Kim YH. Anticomplement activity of terpenoids from the spores of Ganoderma lucidum. Planta Med. 2001;67(9):811-814.

[105] Yang QY, Pai SS. The anti-ageing effects of Ganoderma essence. Proceedings of the International Meeting on Ganoderma Science. Beijing; 2000:30.

[106] Suzuki I, Hashimoto K, Oikawa S, Sato K, Osawa M, Yadomae T. Antitumor and immunomodulating activities of a beta-glucan obtained from liquid-cultured Grifola frondosa. Chem Pharm Bull (Tokyo). 1989;37(2):410-413.

[107] Jeong H, Lee JW, Lee KH. Studies on the anticomplementary activity of Korean higher fungi. Korean J Mycol. 1990;18:145-148.

[108] Okamura H, Tsutsi H, Komatsu T, et al. Cloning of a new cytokine that induces IFN-gamma production by T cells. Nature. 1995;378(6552):88-91.

[109] Micallef MJ, Ohtsuki T, Kohno K, et al. Interferongamma-inducing factor enhances $\mathrm{T}$ helper $1 \mathrm{cy}$ tokine production by stimulated human $\mathrm{T}$ cells: synergism with interleukin-12 for interferongamma production. Eur J Immunol. 1996;26(7): 1647-1651.

[110] Hsieh CS, Macatonia SE, Tripp CS, Wolf SF, O'Garra A, Murphy KM. Development of TH1 $\mathrm{CD}^{+} \mathrm{T}$ cells through IL-12 produced by Listeria-induced macrophages. Science. 1993;260(5107): 547-549.

[111] Feldmann M, Brennan FM, Maini RN. Role of cytokines in rheumatoid arthritis. Annu Rev Immunol. 1996;14:397-440.

[112] Cohen PA, Cohen PJ, Rosenberg SA, Mule JJ. CD4 ${ }^{+}$ T-cells from mice immunized to syngeneic sarcomas recognize distinct, non-shared tumor antigens. Cancer Res. 1994;54(4):1055-1058.

[113] O'Garra A, Murphy K. T-cell subsets in autoimmunity. Curr Opin Immunol. 1993;5(6):880-886. 
[114] Powrie F, Coffman RL. Cytokine regulation of Tcell function: potential for therapeutic intervention. Immunol Today. 1993;14(6):270-274.

[115] Scott B, Liblau R, Degermann S, et al. A role for non-MHC genetic polymorphism in susceptibility to spontaneous autoimmunity. Immunity. 1994;1(1):73-83.

[116] Liblau RS, Singer SM, McDevitt HO. Th1 and $\mathrm{Th} 2 \mathrm{CD}^{+} \mathrm{T}$ cells in the pathogenesis of organspecific autoimmune diseases. Immunol Today. 1995;16(1):34-38.

[117] Romagnani S. Regulation of the development of type 2 T-helper cells in allergy. Curr Opin Immunol. 1994;6(6):838-846.

[118] Suzuki Y, Adachi Y, Ohno N, Yadomae T. Th1/Th2balancing immunomodulating activity of gelforming $(1 \rightarrow 3)$ - $\beta$-glucans from fungi. Biol Pharm Bull. 2001;24(7):811-819.

[119] Chihara G, Hamuro J, Maeda YY, et al. Antitumor and metastasis-inhibitory activities of lentinan as an immunomodulator: an overview. Cancer Detect Prev Suppl. 1987;1:423-443.

[120] Murata Y, Shimamura T, Tagami T, Takatsuki F, Hamuro J. The skewing to Th1 induced by lentinan is directed through the distinctive cytokine production by macrophages with elevated intracellular glutathione content. Int Immunopharmacol. 2002;2(5):673-689.

[121] Inoue A, Kodama N, Nanba H. Effect of Maitake (Grifola frondosa) D-fraction on the control of the T lymph node Th-1/Th-2 proportion. Biol Pharm Bull. 2002;25(4):536-540.

[122] Harada N, Kodama N, Nanba H. Relationship between dendritic cells and the D-fraction-induced Th-1 dominant response in BALB/c tumor-bearing mice. Cancer Lett. 2003;192(2):181-187.

[123] Hsu HC, Hsu CI, Lin RH, Kao CL, Lin JY. Fip-vvo, a new fungal immunomodulatory protein isolated from Volvariella volvacea. Biochem J. 1997;323(pt 2):557-565.

[124] She QB, Ng TB, Liu WK. A novel lectin with potent immunomodulatory activity isolated from both fruiting bodies and cultured mycelia of the edible mushroom Volvariella volvacea. Biochem Biophys Res Commun. 1998;247(1):106-111.

[125] Bao XF, Wang XS, Dong Q, Fang JN, Li XY. Structural features of immunologically active polysaccharides from Ganoderma lucidum. Phytochemistry. 2002;59(2):175-181.

[126] Bao X, Fang J, Li X. Structural characterization and immunomodulating activity of a complex glucan from spores of Ganoderma lucidum. Biosci Biotechnol Biochem. 2001;65(11):2384-2391.

[127] Zhang J, Tang Q, Zimmerman-Kordmann M, Reutter W, Fan H. Activation of B lymphocytes by GLIS, a bioactive proteoglycan from Ganoderma lucidum. Life Sci. 2002;71(6):623-638.
[128] Kim GY, Park SK, Lee MK, et al. Proteoglycan isolated from Phellinus linteus activates murine B lymphocytes via protein kinase $\mathrm{C}$ and protein tyrosine kinase. Int Immunopharmacol. 2003;3(9):12811292.

[129] Di Renzo L, Yefenof E, Klein E. The function of human NK cells is enhanced by beta-glucan, a ligand of CR3 (CD11b/CD18). Eur J Immunol. 1991;21(7):1755-1758.

[130] Kino K, Sone T, Watanabe J, et al. Immunomodulator, LZ-8, prevents antibody production in mice. Int J Immunopharmacol. 1991;13(8):1109-1115.

[131] Ko JL, Hsu CI, Lin RH, Kao CL, Lin JY. A new fungal immunomodulatory protein, FIP-fve isolated from the edible mushroom, Flammulina velutipes and its complete amino acid sequence. Eur J Biochem. 1995;228(2):244-249.

[132] Janeway CA Jr, Medzhitov R. Lipoproteins take their toll on the host. Curr Biol. 1999;9(23):R879R882.

[133] Mueller A, Raptis J, Rice PJ, et al. The influence of glucan polymer structure and solution conformation on binding to $(1 \rightarrow 3)-\beta$-D-glucan receptors in a human monocyte-like cell line. Glycobiology. 2000;10(4):339-346.

[134] Lowe E, Rice P, Ha T, et al. A ( $1 \rightarrow 3)-\beta$-D-linked heptasaccharide is the unit ligand for glucan pattern recognition receptors on human monocytes. Microbes Infect. 2001;3(10):789-797.

[135] Kougias P, Wei D, Rice PJ, et al. Normal human fibroblasts express pattern recognition receptors for fungal $(1 \rightarrow 3)-\beta$-D-glucans. Infect Immun. 2001;69(6):3933-3938.

[136] Brown GD, Gordon S. Fungal $\beta$-glucans and mammalian immunity. Immunity. 2003;19(3):311-315.

[137] Ross GD, Cain JA, Myones BL, Newman SL, Lachmann PJ. Specificity of membrane complement receptor type three (CR3) for beta-glucans. Complement. 1987;4(2):61-74.

[138] Zimmerman JW, Lindermuth J, Fish PA, Palace GP, Stevenson TT, DeMong DE. A novel carbohydrateglycosphingolipid interaction between a $\beta$-(1-3)glucan immunomodulator, PGG-glucan, and lactosylceramide of human leukocytes. J Biol Chem. 1998;273(34):22014-22020.

[139] Rice PJ, Kelley JL, Kogan G, et al. Human monocyte scavenger receptors are pattern recognition receptors for $(1 \rightarrow 3)-\beta$-D-glucans. J Leukoc Biol. 2002;72(1):140-146.

[140] Brown GD, Gordon S. Immune recognition. A new receptor for beta-glucans. Nature. 2001;413(6851): 36-37.

[141] Shao BM, Dai H, Xu W, Lin ZB, Gao XM. Immune receptors for polysaccharides from Ganoderma lucidum. Biochem Biophys Res Commun. 2004;323(1):133-141. 
[142] Herre J, Gordon S, Brown GD. Dectin-1 and its role in the recognition of $\beta$-glucans by macrophages. Mol Immunol. 2004;40(12):869-876.

[143] Taylor PR, Brown GD, Reid DM, et al. The $\beta$ glucan receptor, dectin-1, is predominantly expressed on the surface of cells of the monocyte/macrophage and neutrophil lineages. J Immunol. 2002;169(7):3876-3882.

[144] Kim HM, Han SB, Oh GT, et al. Stimulation of humoral and cell mediated immunity by polysaccharide from mushroom Phellinus linteus. Int J Immunopharmacol. 1996;18(5):295-303.

[145] Liu M, Li J, Kong F, Lin J, Gao Y. Induction of immunomodulating cytokines by a new polysaccharide-peptide complex from culture mycelia of Lentinus edodes. Immunopharmacology. 1998; 40(3):187-198.

[146] Bao X, Liu C, Fang J, Li X. Structural and immunological studies of a major polysaccharide from spores of Ganoderma lucidum (Fr) Karst. Carbohydr Res. 2001;332(1):67-74.

[147] Hsiao WL, Li YQ, Lee TL, Li N, You MM, Chang ST. Medicinal mushroom extracts inhibit ras-induced cell transformation and the inhibitory effect requires the presence of normal cells. Carcinogenesis. 2004;25(7):1177-1183.

[148] Shigesue K, Kodama N, Nanba H. Effects of Maitake (Grifola frondosa) polysaccharide on collagen-induced arthritis in mice. Jpn J Pharmacol. 2000;84(3):293-300.

[149] Han SN, Wu D, Leka LS, Meydani SN. Effect of mushroom (Coriolus versicolor) extract on the immune response of young and old mice. FASEB J. 1996;10(3):3200.

[150] Chihara G, Hamuro J, Maeda Y, Arai Y, Fukuoka F. Fractionation and purification of the polysaccharides with marked antitumor activity, especially lentinan, from Lentinus edodes (Berk) Sing (an edible mushroom). Cancer Res. 1970;30(11):27762781.

[151] Suga T, Shiio T, Maeda YY, Chihara G. Antitumor activity of lentinan in murine syngeneic and autochthonous hosts and its suppressive effect on 3methylcholanthrene-induced carcinogenesis. Cancer Res. 1984;44(11):5132-5137.

[152] Ooi VE, Liu F. Immunomodulation and anticancer activity of polysaccharide-protein complexes. Curr Med Chem. 2000;7(7):715-729.

[153] Cui J, Chisti Y. Polysaccharopeptides of Coriolus versicolor: physiological activity, uses, and production. Biotechnol Adv. 2003;21(2):109-122.

[154] Yang QY, Jong SC, Li XY, Zhou JX, Chen RT, Xu LZ. Antitumor and immunomodulating activities of the Polysaccharide-Peptide (Psp) of Coriolus versicolor. Eos-Riv Immunol. 1992;12:29-34.

[155] Zhu R, Chen X, Lan J. Advance in the study on liquid fermentation for medicinal fungi. Zhong Yao Cai. 2003;26(1):55-57. 


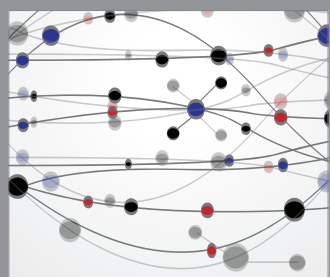

The Scientific World Journal
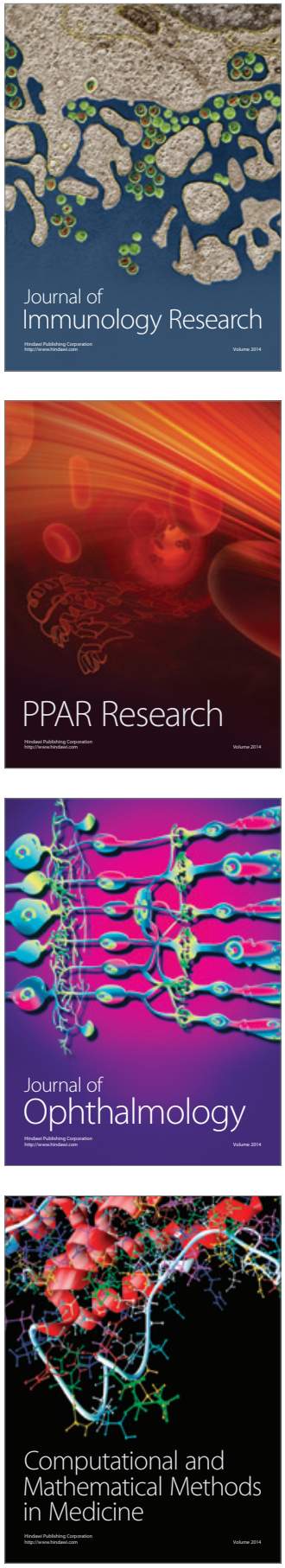

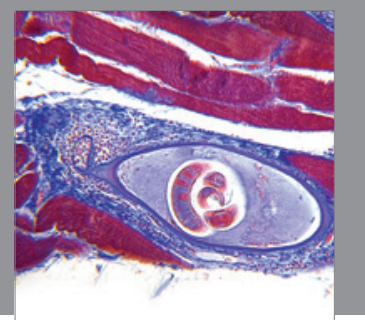

Gastroenterology

Research and Practice
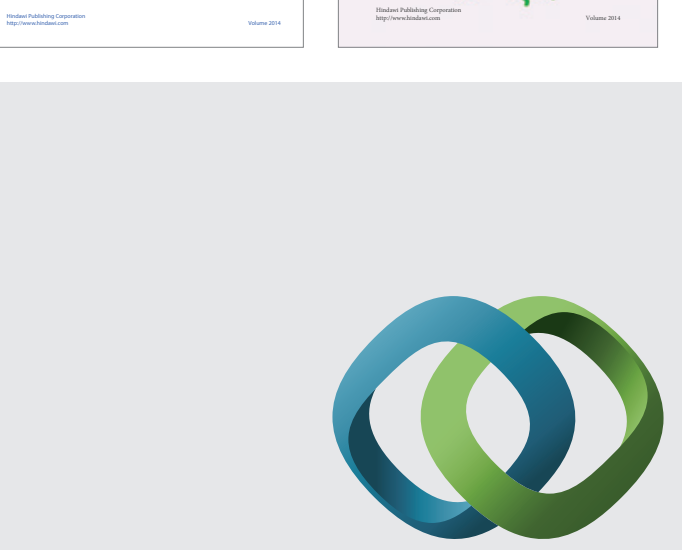

\section{Hindawi}

Submit your manuscripts at

http://www.hindawi.com
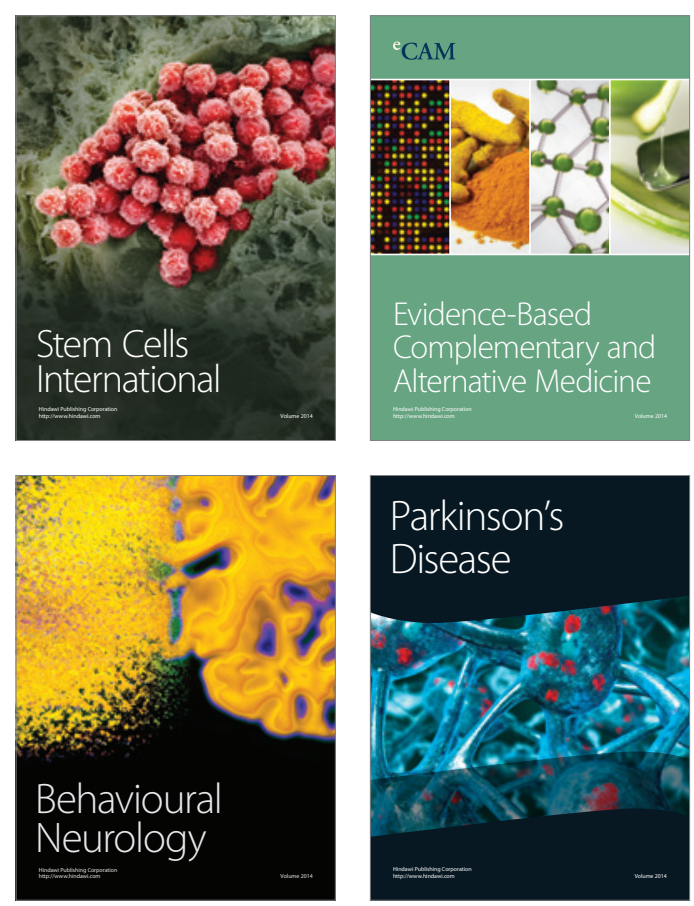

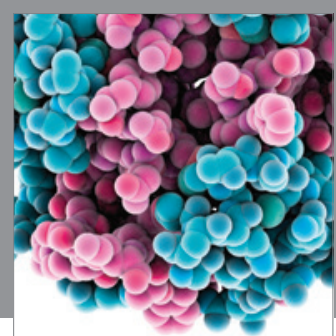

Journal of
Diabetes Research

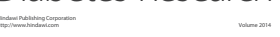

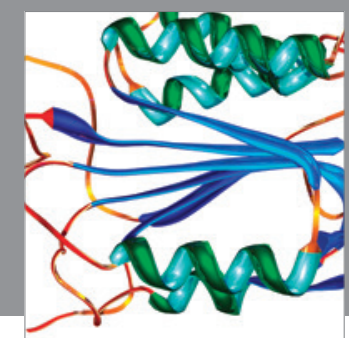

Disease Markers
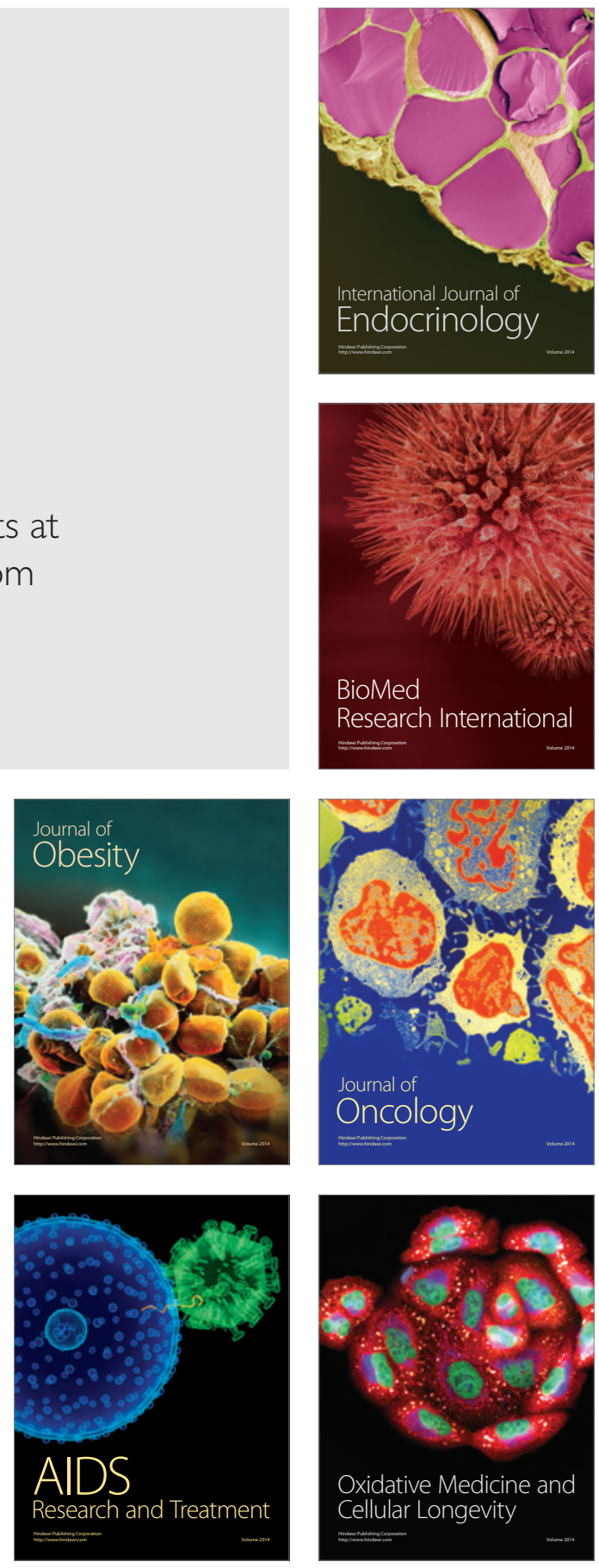